\title{
An analysis of design strategies for circular economy through life cycle assessment
}

\author{
Christian Spreafico $\mathbb{D}$
}

Received: 13 August 2021 / Accepted: 22 January 2022 / Published online: 14 February 2022

(C) The Author(s) 2022

\begin{abstract}
The goal of pursuing the circular economy (CE) is spreading more and more in industry, also driven by the introduction of new regulations, considerably affecting product design. However, a quantitative and rigorous evaluation of the environmental impacts of the results obtained by different design strategies used to implementing $\mathrm{CE}$ is missing in the literature. Those available only evaluate certain aspects of the life cycle of few products, belonging to specific application fields, in a qualitative way or they refer only to the global warming potential. This study provides a quantitative assessment of the environmental impacts reductions arising from the application of some common design strategies for implementing different CE options (e.g. reuse, waste
\end{abstract}

\section{Highlights}

- Environmental impact reductions obtained through design strategies for $\mathrm{CE}$ were evaluated.

- One hundred fifty-six case studies from scientific articles about comparative LCA and 5 impact categories were considered.

- Average impact reduction of each strategy is $22-53 \%$ compared to disposal the baseline scenario (where wastes are not exploited).

- The hierarchy of CE options based on environmental impacts is variable according to the impact categories.

- Sustainability of CE options mainly depends by the used design strategies and the product features.

C. Spreafico $(\bowtie)$

Department of Management, Information and Production Engineering, University of Bergamo, Via Marconi 5, 24044 Dalmine, Bergamo, Italy

e-mail: christian.spreafico@unibg.it to energy, remanufacturing), by using some standard indicators. The results were obtained by manually analysing 156 selected case studies of comparative life cycle assessment (LCA), extracted from 136 scientific articles. In them, the environmental impacts of design solutions for $\mathrm{CE}$ are compared with those of other solutions were wastes are not exploited. The obtained results have been used to evaluate the different design strategies for $\mathrm{CE}$ and to hierarchize them based on environmental sustainability of the solutions associated with them. In addition, an economic evaluation of the strategies, based on the life cycle costing methodology and exploiting the data available in the same articles, was also provided. Among the main achievements, it was found that the hierarchy of the CE options, pursued by the design strategies, to improve environmental sustainability is different from that provided by other studies. In addition, the environmental benefits associated with the different $\mathrm{CE}$ options strictly depend by the applied design strategies and the considered products.

Keywords Design strategies - Circular economy · Life cycle assessment (LCA) · Eco-design · Literature review

\section{Introduction}

The implementation of the circular economy (CE) is increasingly becoming a fundamental requirement to be 
achieved during product design. As a result, the evaluation of the design solutions is significantly changing too in this direction and new aspects are considered. Products should be more robust to increase the operative life and reduce maintenance interventions (e.g. Van den Berg \& Bakker, 2015). The same components must be more durable to be reused in new product after the disposal (e.g. Marino \& Marrone, 2020). Any intervention on the product, during maintenance and disassembly, must be carried out by reducing the required energy and auxiliary materials. For this reason, the products should also be designed for the disposals as well as to guarantee the functioning (e.g. Rios et al., 2015). During the design, every aspect of the life cycle of a product must be seen as an opportunity, looking for its value. Consequently, an unusable product must be recycled as much as possible and energy must be obtained from the disposal of non-recyclable parts, by creating new synergies with the supply chain of the same and other products (e.g. Habagil et al., 2020; Yuan et al., 2014).

In the literature, some authors identified and classified strategies, methods and tools supporting product design to favour the transition to CE. These works highlighted the numerosity and the heterogeneity of the many supporting approaches and the criteria to be consider for selecting the most suitable ones (e.g. Bocken et al., 2016; Mestre \& Cooper, 2017). Among them, there are the type of waste to be recovered, the type of product that generates or becomes the waste and the CE option to implement (e.g. reuse, recycle, remanufacturing). The pros and cons of different design approaches, emerged from these studies, also highlighted that an eco-design method cannot be considered better than a generic design method in absolute terms, and vice versa, in proposing solutions for $\mathrm{CE}$ - this despite the fact that the implementation of the $\mathrm{CE}$ requires to solve many of the problems that eco-design methods typically face (Den Hollander et al., 2017).

Thus, these studies, through environmental assessment, showed that merit of the higher sustainability of CE options depends by the application of the supporting design strategies. In fact, some preferential hierarchies between the different CE options regarding sustainability were provided (e.g. Behrens et al., 2007), but the application of different design strategies could make a $\mathrm{CE}$ option more sustainable than others, by reversing the hierarchy (Bocken et al., 2016). For this reason, the evaluation of the environmental benefits that the application of the different design strategies for $\mathrm{CE}$ can guarantee is therefore fundamental for eco-design and for implementing the same CE.

However, the studies supporting this assessment (see "State of the art") have some limitations. The number of design strategies compared in each study is generally reduced. The considered scenarios and boundary conditions are too different, by making it difficult the normalization of the results. Because of the reduced number of considered case studies and their homogeneity, the design strategies are difficult to be evaluated in a domain-independent manner. The analyses have not always been carried out by rigorously following the reference standards. In many cases, the provided assessment is subjective and, consequently, they are difficult to compare. Finally, the impacts are usually expressed only through the carbon footprint.

This study proposes an evaluation of the environmental benefits arising from different products as a result of the application of different design strategies to support $\mathrm{CE}$, which have been carefully selected in the literature. This assessment was conducted on 156 case studies from scientific articles based on life cycle assessment (LCA) according to ISO 14040 (ISO, 2006a) and ISO 14044 (ISO, 2006b). LCA methodology was considered due to its reliability in quantitatively evaluating the sustainability of the current technologies, critically discussing the choices to implement during eco-design and evaluating the environmental performances of new developed technologies (Hauschild et al., 2018).

The research questions to which this study aims to answer are the following:

- RQ. 1: Is there a preferred hierarchy among the different CE options in terms of environmental sustainability, or does the hierarchy depend on the application of the different design strategies?

- RQ. 2: Can indications about how to apply the design strategies to obtain the greatest environmental benefits according to the addressed problem be isolated?

The novelty and the importance of this studies lie in the method used to answer these questions. Compared to other studies in the literature, the evaluation of the design strategies, provided in this study, is less influenced by the specific features of the application 
fields. This is because more case studies, referring to a greater number of application fields, and with greater heterogeneity, were analysed. In addition, to reduce the influence of the design approach, followed to implement a CE option, alternative design strategies to achieve some of them were compared. The provided environmental assessment was improved, compared to the previous contributions from the literature, by expressing the environmental impacts through different standard categories and considering the entire life cycle of the analysed products.

These aspects allow to provide reliable and rigorous answers to the research questions and to confirm some considerations previously formulated by other studies in the literature. One of them is the official "waste hierarchy", supported by studies (e.g. Zunft $\&$ Fröhlig, 2009) and reference bodies (e.g. European Union Council Directive 2008/09/EC). According to it, the CE options "reduce waste", "reuse", "remanufacturing", "recycle" and "waste to energy" can be ordered on the basis of the environmental sustainability regardless of the application field. On the contrary, the obtained results could confirm if the same hierarchy is instead dependent on this latter and on the followed design strategies (e.g. Behrens et al., 2007). In addition, extended quantitative results about design strategies for CE can provide the knowledge base required by those studies that drawn the plan to teach CE (e.g. Saidani et al., 2021).

\section{State of the art}

Several studies about the assessment of environmental sustainability achievable in a product through the application of design strategies for $\mathrm{CE}$ can be retrieved in the literature. By analysing those collected through the keywords "eco-assessment", "product design", "circular economy" and synonyms in Google Scholar and SCOPUS, the following differences emerge.

Some studies consider only the design strategies explicitly referred to CE. The most diffused ones suggest how to design a product to reduce waste, improve disassembly and recycle. Such strategies generally derive from generic design strategies (e.g. Cayzer et al., 2017) or from eco-design methods (e.g. Smol et al., 2017). Other studies (e.g. Boavida et al., 2020) analyse the effectiveness of design strategies, e.g.
TRIZ, in the context of environmental sustainability but without referring to $\mathrm{CE}$, although their insights can be used to implement it. Furthermore, depending on the case, the considered design strategies may refer to routine design (e.g. Garcia-Muiña et al., 2019), suggesting structural optimization and material replacement, or innovative design (e.g. Ozkeser, 2018), suggesting disruptive modalities to modify the product.

The design strategies were applied in different ways in these studies. In some cases, only a single one, while in other cases, at least a design strategy is considered for each CE option (e.g. Lieder et al., 2017). The main limitation of both these approaches is the comparison between the different design strategies. In contrast, the studies comparing multiple design strategies for each $\mathrm{CE}$ option do not have this limitation (e.g. Cayzer et al., 2017).

The number of case studies considered during the evaluations varies in the different contributions from the literature. Many papers provide a single case study about a specific application field (e.g. Moussa et al., 2019; Santagata et al., 2020); others consider more case studies but generally no more than ten, except for Spreafico (2021). The most difficult studies to compare are the ones they propose a single case study and a single design strategy (e.g. Liu et al., 2019).

The evaluation of the environmental benefits guaranteed on the product by the application of the design strategies can be carried out following a rigorous method, such as the LCA, by following its related standards (e.g. Garcia-Muiña et al., 2019), or other qualitative approaches of evaluation (e.g. Feniser et al., 2017).

Not always, the provided environmental impacts are expressed through standard categories. In the case, $\mathrm{CO}_{2}$ eq. (e.g. Smol et al., 2017) is the most common, although the use of this single indicator has been considered a limitation in quantifying the actual benefits of CE (Bocken et al., 2016). Non-standard categories are instead the reduction of the mass of the product and the produced waste (e.g. Boavida et al., 2020), the reduction of energy consumption (Ozkeser, 2018) and the reduction of the polluting emissions (Bersano et al., 2017).

Finally, regardless of the considered approach and environmental impact indicators, the provided assessment can be quantitative or qualitative. For instance, 
Cayzer et al. (2017) interviewed several managers of companies that had triggered a successful transition to $\mathrm{CE}$ by applying design strategies and provided their qualitative assessments.

\section{Tested design strategies for circular economy}

With the aim of providing a broad overview of the many design strategies that can be used to implement the CE, in this study, a selection of those most discussed in the literature, for each CE option, was analysed. The considered CE options are reducing waste, using renewable energies, reuse, remanufacturing, recycling, product waste energy recovery, disposal, transforming waste into energy. In the following, a brief description of each strategy is proposed, along with the presentation of some sub-strategies with which these strategies can be declined. The starting point for retrieving the considered strategies was the work of Den Hollander et al. (2017). In that study, the authors collected generic design strategies and showed how their application can change in linear economy and in CE contexts, while the order of presentation of the design strategies is consistent with the hierarchy of EC directive 2008/09/EC (Zunft \& Fröhlig, 2009) concerning the environmental sustainability of the different CE options (in descending order) to which the design strategies refer.

\section{Design for reducing wastes}

Design for reducing wastes aims to ensure that the wastes generated from the product (i.e. exhaust components and auxiliary materials/consumables) during use and end of life are limited (Keys et al., 2000). In the literature, this strategy has been declined in different ways, which have also been considered in this study. Structural optimization (e.g. Russo \& Rizzi, 2014) is used to reduce product mass through structural rearrangement, (acting on the shape) or microstructural rearrangement (acting on the internal organization) of the structure. Fluid dynamic optimization (Cheshmehzangi et al., 2017) is used to reduce the mass of a fluid by modifying its local or global fluid dynamic conditions (e.g., pressure, temperature, flow rate, turbulence, spatial distribution) while ensuring its functions (e.g., heat transfer, thrust). Finally, dematerialization is a more innovative way to solve the problem and it is also counted among the principles of TRIZ (Russian acronym for Theory of
Inventive Problem Solving) (Altshuller, 1984), one of the best known methods to support technical problemsolving. Its objective is to eliminate the components of a product, delegating their functionality to other ones or to the external environment, or to replace them with a field. Two typical examples are self-cleaning glasses, exploiting catalytic elements activated by sunlight to avoid detergents and laser cutting to replace a sawcut.

Design for using renewable energies

The goal of this strategy is to improve the product functioning by introducing dedicated technologies able to exploit renewable energy, by reducing the consumptions (e.g., Nakata et al., 2005). The prerequisites of this activity are the research of the renewable energy source and the definition of its compatibility with product functioning rhythms, e.g. the hourly profile in the case of solar energy.

\section{Design for reuse}

Reuse is the simplest way to satisfy one of the three macro-objectives of the CE, i.e. keeping products and materials in use, by reusing the product and its materials, after the operative life, without transforming them. To put this strategy into practice, however, it may be necessary to intervene appropriately on the product, even redesigning its structure, through "Design for reuse" rules and suggestions. This activity within CE has the objective of encouraging the user to reuse the product for the same or other uses, by improving the resistance of the product's structure (Hooton \& Bickley, 2014). Alternatively, the structure can be improved to be more easily reconverted to possible future users' needs (Torroja et al., 1997). From the environmental point of view, the product must also be designed to encourage the reuse on site in order to reduce the impacts of the relocation (Friedler, 2004).

\section{Design for remanufacturing}

The goal of this strategy is to encourage the remanufacturing of a product after the operative life, so that it can be perform its functions again or perform other functions. According to this strategy, the remanufacturing operations are also improved by reducing energy and resource consumption to increase environmental sustainability (Nasr \& Thurston, 2006). At the application level, the same strategy is implemented 
with the choice of the most appropriate technology to perform remanufacturing and the definition of the use modality (e.g. Haziri \& Sundin, 2019).

\section{Design for recycling}

The task of this strategy is to identify materials that can be recycled and use them to realize the product, without affecting its functionality, and facilitating at the same time product recycling, disassembly and other preliminary operations (Kriwet et al., 1995). At a general level, this strategy can be obtained in two different modalities, both evaluated in this study. They depend on the output of the recycling and the involved technologies. In the case of ecosystem restoration, the objective is to regenerate the biological cycles of various ecosystems (e.g. forests, fresh water, inland wetlands) through different processes (e.g. extraction of biochemical feedstock, farming and anaerobic digestion) (De Groot et al., 2013), while, in the case of technical recycling, the objective is to regenerate the technical cycles, by reproducing the product constituent materials (EC directive 2008/09/ $\mathrm{EC})$, such as in the case of recycled paper and plastic.

\section{Design for energy recovery}

This strategy aims to improve the product by reducing the wasted energy through the introduction of devices dedicated to its recovery and reuse within or without the same product (Den Hollander et al., 2017). To implement the strategy, the modalities and the technologies to recover energy must be determined and implemented. Some examples are the heat exchangers for the hot fumes and the kinetic energy recovery system (KERS) for the recovery of kinetic energy in vehicles during braking. In this study, the environmental benefits of the Design for energy recovery were evaluated only through the thermal energy recovery.

Design for disposal (using biodegradable materials)

The goal of this strategy is to reduce the environmental impacts of the product disassembly by improving the structure of the same product. For this reason, biodegradable materials decompose more quickly, emitting fewer pollutants and requiring fewer resources are preferred (Den Hollander et al., 2017). In general, the design directions starting from this strategy are the reduction of the quantity of material to be disposed and its replacement with a more easily disposable material. In this study, only the second option was considered to differentiate this strategy from "Design for reducing wastes" strategy. Biodegradable materials can be substituted to synthetic materials or used in combination with them (e.g., cement filled with rocks). They can be natural material or based on natural materials, such as bio-based polymers (Godavitarne et al., 2017).

\section{Design for recovering energy from waste}

The objective of this strategy is to select the most appropriate processes and technologies to dispose the product, maximizing the obtained energy from its decomposition and reducing the generated pollutants. The product characteristics are carefully analysed to select the most appropriate disposal technology and the structure of the product can be modified to facilitate the previous disassembly (Den Hollander et al., 2017).

\section{Methodology}

This section presents the methodology followed to evaluate the considered design strategies for CE. As in Spreafico (2021), the main assumption of the followed methodology is to base the analysis on case studies about comparative LCA collected from the literature instead of replicate LCA from scratch. In this case, two real options for treating waste were considered. The comparison between the second option and the first option was manually interpreted by the author as the application of a Design strategy for CE, among those presented in "Tested design strategies for circular economy".

By considering LCA studies published in the literature, the comparison is enlarged, since many more case studies can be collected in a reasonable time. Another advantage of this choice is to improve the reliability of the results, since they are collected from peer-reviewed studies published in prestigious international journals. Finally, the choice to consider comparative LCA studies allowed to exclude the necessary subjective assumptions to compare the results of independent studies, based on different scenarios, boundaries conditions and functional units.

Each step of the followed methodology is explained in detail the following sub-sections. 
PHASE 1 - collecting the case studies from the literature

To ensure the reliability of the results, only articles published in indexed international peer-review journals about comparative LCA were considered in this study. These documents were searched in Scopus and Google Scholar databases, by using the following query (referred to Scopus syntax): "compar* AND (LCA OR (life W/ cycle W/ assessment))". In addition, to provide an updated analysis, only the articles published since 2010 were considered. The intentional generality with which the query was formulated was necessary to retrieve all the relevant documents, given the vastness of the topic and the many ways to refer to the applications of design strategies for CE. To isolate the relevant documents, it was necessary to opt for a manual search, despite the burden required by the same. The manual search that made it possible to collect the relevant articles was conducted in title and abstract, searching for the actual proposal of comparative LCA and a summary mention of the application of one of the design strategies for $\mathrm{CE}$ described in "Tested design strategies for circular economy".

Therefore, the previously selected documents were manually analysed throughout the text, applying a rigorous selection based on the following criteria.

1. At least two real options of waste processing are described and compared though LCA methodology.

2. The two options consider the same waste, which is processed, albeit in different ways, in the same operating scenario and their comparison is based on a unique functional unit.

3. The alternative waste management option is presented in an exhaustive manner, reporting all the features necessary to understand which design strategy for CE has been applied.

4. The baseline option actually represents a true scenario and not a pejorative comparison term that is used only to enhance in the comparison the characteristics of what is proposed in the articles, i.e. the second option. This control was performed by considering additional assessments about the baseline scenario of the given waste that were inferred from the scientific literature.

5. The environmental impacts of the two options are assessed using the same calculation procedure.
6. The results of the two LCAs of the two options are expressed according to the same impact categories.

The final pool, after the selection, counts 156 case studies, extracted from 136 articles.

PHASE 2 - classifying the case studies according to the design strategies for circular economy

The classification of the case studies according to the considered design strategies for CE was manually performed. The reliability of this process and its repeatability are favoured by the precise definitions that have been collected for the design strategies and their many sub-strategies, reported in "Tested design strategies for circular economy", and by the rigorous document selection process, presented in "PHASE 1 - Collecting the case studies from the literature". Thanks to this process, all the considered case studies describe very clearly both the referred CE options (e.g. reuse, recycling) and the design strategies (or sub-strategies) that have been implemented.

PHASE 3 - extracting data from the case studies

In this phase, the environmental impacts resulting from the life cycle of each considered option from the case studies were extracted. The selected impact categories are the most common in the literature and include both global and local effects affecting both environment and humans.

The selected impact categories are:

- Global warming potential (GWP), expressed in $\mathrm{kg}$ $\mathrm{CO}_{2}$ eq.

- Acidification potential (AP), expressed in $\mathrm{kg} \mathrm{SO}_{2}$ eq.

- Eutrophication potential (EP), calculated as the arithmetic mean of terrestrial, fresh water and marine eutrophication and expressed in $\mathrm{kg} \mathrm{P}$ eq.

- Particulate matter formation (PMF), considering the production of PM2.5 or PM10 or their arithmetic mean if both are available and expressed in grams per cubic metre.

- Resource depletion (RD), obtained from the arithmetic mean of mineral, fossil, and non-renewable resource depletion indicators, and expressed in MJ.

- Water consumption (WC), expressed in cubic metre. 
- Average impact, calculated as the arithmetic mean of the percentage reduction (see PHASE 4) of all the considered indicators.

PHASE 4 - quantifying the eco-sustainability of the design strategies for circular economy

The percentage reduction in each environmental impact category $(j)$ associated with each design strategy for CE $(x)$ was calculated as the arithmetic mean of the percentage reductions in the same impact category in all the $(\mathrm{N})$ case studies referred to that Design strategy.

$\% \mathrm{I}_{\mathrm{j}}$ reduction $_{\text {Strategy } \mathrm{x}}=\frac{\sum_{\mathrm{i}=1}^{\mathrm{N}} \% \mathrm{I}_{\mathrm{j}, \mathrm{i}} \text { reduction }}{\mathrm{N}}$

In turn, the percentage reduction of the given environmental impact category $(j)$ in a case study $(k)$ was calculated as the difference of the environmental impact, of the same category, of option 2 and that of option 1, divided by the environmental impact of option 2. This latter is the one resulting from the application of a Design strategy for CE, according to the performed association, when compared to option 1 .

$\% \mathrm{I}_{\mathrm{j}, \mathrm{k}}$ reduction $=\frac{\mathrm{I}_{\mathrm{j}, \mathrm{k}}\left(\text { option2) }-\mathrm{I}_{\mathrm{j}, \mathrm{k}}(\text { option } 1)\right.}{\mathrm{I}_{\mathrm{j}, \mathrm{k}}(\text { option } 2)}$

For instance, the paper of Agarski et al. (2017) compares the environmental impacts of catalyst fluid (option 1) and ultrasonic aerosol (option 2) to perform a chemical synthesis process. This case study was associated with the "Design for reducing waste" strategy because option 2 allows to eliminate the catalyst fluid that is instead used and disposed in option 1. While in the paper of Akhshik et al. (2017) the environmental impacts of two engine beauty covers made by different materials are compared: fiberglass (option 1) and bio-based material (option 2). This case study was associated with the "Design for disposal" strategy, because option 2 can be disposed more easily than option 1 and it is biodegradable. The complete list of the two options compared in each case study and the associated Design strategies for $\mathrm{CE}$ are reported in Table 4 in the Appendix.

The same method was also used to evaluate the economic convenience of the Design strategies for CE. In this case, the costs of the two options have been substituted to the environmental impacts in Eq.
(2). These costs were also extracted from the considered articles and were obtained, in the same, through the life cycle assessment (LCC) methodology, which is the equivalent methodology of the LCA, used for evaluating the costs instead of the environmental impacts.

\section{Results and discussion}

In this section, the obtained are presented and discussed in detail. A specific order was chosen for their presentation according to the increasing of the level of detail. In this way, the reader can initially learn the main results obtained by comparing all the tested design strategies for $\mathrm{CE}$ and then the motivations behind the results. For this reason, the presentation of the results goes into the merits of the individual design strategies and discusses the advantages and disadvantages of specific applications according to all the considered environmental impact categories.

Table 4 in the Appendix reports all the considered articles, the extracted case studies, their classification and the considered data about the percentage reductions of the impact categories and costs extracted from them.

The main result obtained from this study is the comparison of the different design strategies for CE, associated with the considered case studies, based on the average percentage reductions of environmental impacts (see Fig. 1).

Figure 1 clearly shows the environmental impact reduction of the Average indicator associated with Design for remanufacturing (53\%) and Design for recycling (45\%), and the disadvantages of Design for recovering energy from waste, where the average impact increased by $83 \%$. However, this result only partially confirms RQ. 1 (i.e. "Is there a preferred hierarchy among the different CE options in terms of environmental sustainability, or does the hierarchy depend on the application of the different design strategies?'). In fact, Design for recovering energy from waste is the worst option, and a trend in reducing the average impact can be noted by moving from Design for manufacturing to this latter. However, the first three options do not follow this trend, contrarily to Zunft and Fröhlig (2009). Other studies (e.g. Amponsah et al., 2012; Cai \& Waldmann, 2019) are aligned with this result: in them, reuse option is not more sustainable than recycling for certain materials. Anyway, 
Fig. 1 Percentage impact reductions of the average impact associated with each design (D.) strategy for CE resulted from the analysis of the considered case studies (c.s.)

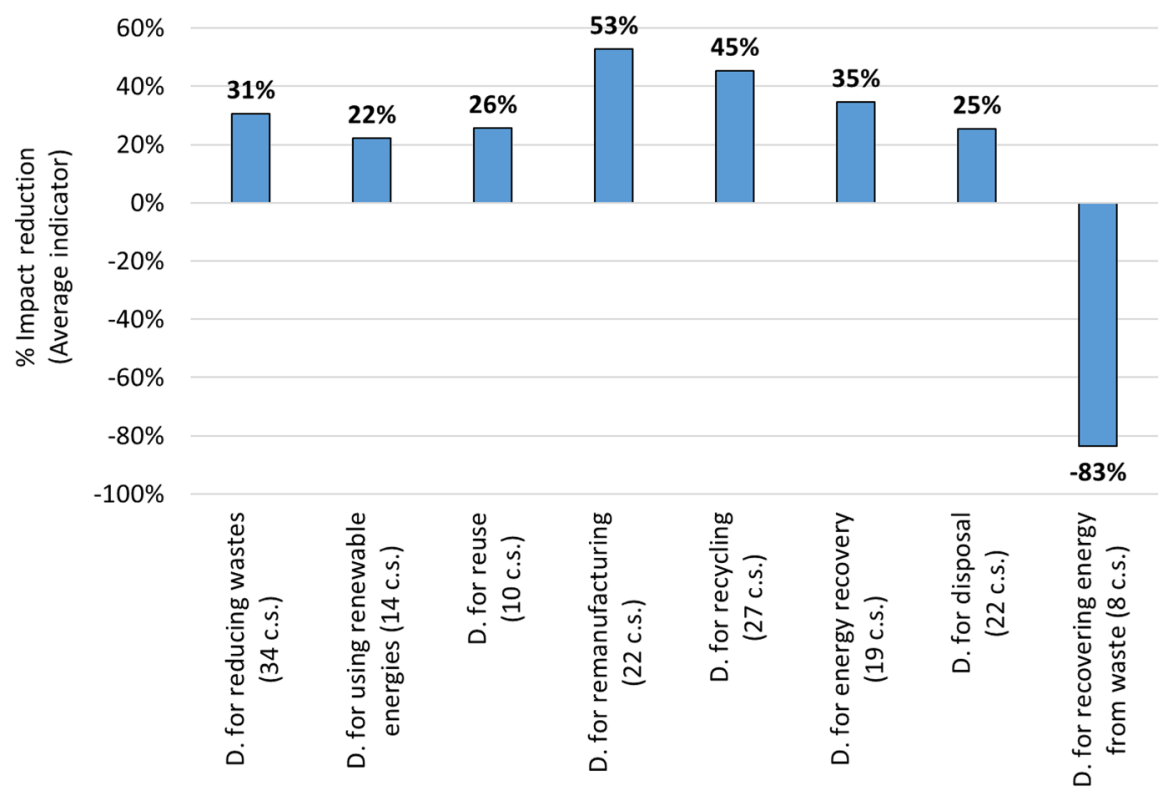

the present study extended the perspective of this analysis that is generally limited to a certain application field in the other studies. To better understand the result of the average impact, Fig. 2 proposes the same comparison between the tested design strategies for $\mathrm{CE}$, by providing all the considered environmental impact categories.

In addition, Table 1 provides the value of the standard deviations associated with the percentage reductions of the environmental impact categories for each considered design strategies (showed in Figs. 1 and 2).

By analysing Fig. 2, the categories of environmental impact that have most influenced the average results of each design strategy can be found. In the case of Design for remanufacturing, the reductions of all the categories are higher than the average, thus confirming the advantages of this strategy at a general level. The result of Design for recycling mainly benefited of the high reductions of EP, PMF and WC. Design for reducing wastes and Design for reuse have lower impact reduction values in all the impact categories. While Design for using renewable energies obtained the highest percentage reduction of $\mathrm{RD}$ and a good reduction of GWP, and a negative result of WC. Finally, Design for recovering energy from waste obtained the highest reduction of AP and negative results of RD, GWP and PMF.

In the following sections, the results obtained for each strategy are discussed in detail and according to each category of environmental impact, in order to identify the reasons about the method of application of the strategy and the application field.

Design for reducing wastes

To understand the reasons of the results obtained for this design strategy, the case studies associated with it were divided between two sub-strategies: Material optimization (15 case studies) (e.g. Villanueva-Rey et al., 2018) and Dematerialization (19 case studies) (e.g. Joseph et al., 2015). Figure 3 shows the percentage reductions of the environmental impact categories that have been associated with these sub-strategies in the considered case studies.

Analysing Fig. 3, Dematerialization resulted batter than Material optimization, by allowing a higher percentage reduction (4\%) of the average impact. This result was favoured in particular by the higher reduction of GWP, AP, EP and RD of Dematerialization, while Material optimization was better for reducing PMF and WC.

The case studies associated with Material optimization were further divided into those proposing Structural optimization (10 case studies) and Fluid dynamic optimization (5 case studies), where in Structural optimization, the mass of the product is reduced by optimizing the shape or the internal structure (e.g. Ahmed \& Tsavdaridis, 2018), while in Fluid dynamic optimization the flow is rationalized, e.g. by increasing its turbulence (e.g. Agarski et al., 2017). Although limited 


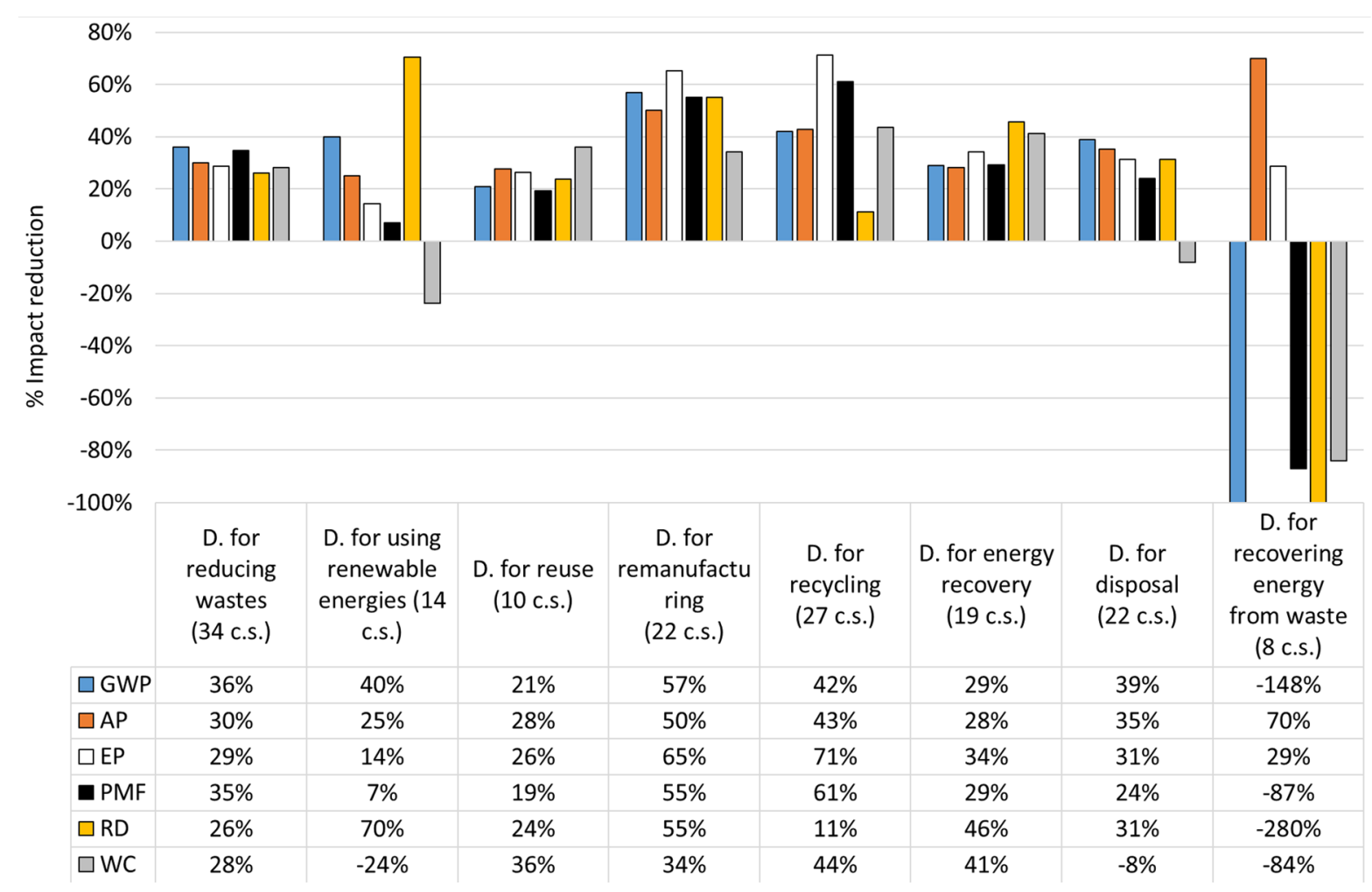

Fig. 2 Percentage reductions of each environmental impact category associated with each design (D.) strategy for CE resulted from the considered case studies (c.s.)

to few overall case studies, this additional subdivision highlighted the major advantages of Fluid dynamic optimization compared to Structural optimization: Average impact ( $42 \%$ vs. $22 \%$ ), GWP (44\% vs. $21 \%$ ), AP (32\% vs. $16 \%)$, EP (33\% vs. $12 \%)$, PMF (58\% vs. $28 \%$ ), RD (32\% vs. $13 \%)$, WC ( $26 \%$ vs. $55 \%)$.

An alternative way to discuss Design for reducing waste strategy is instead in relation to the physical principle on which the solutions are based. To do this, the case studies were divided into those where the physical principle is modified (19 case studies) and the others (15 case studies). Some case studies associated with the first category are casting vs. additive manufacturing for the realization of a semi-finished product (Bekker \& Verlinden, 2018), traditional vs. pulsator washing machine (Spreafico \& Russo, 2020), roll paper vs. blower for drying hands (Joseph et al., 2015). From this classification are highlighted the advantages

Table 1 Standard deviations associated with the percentage reductions of the environmental impact categories for the considered design strategies for $\mathrm{CE}$

\begin{tabular}{|c|c|c|c|c|c|c|c|}
\hline & GWP & $\mathbf{A P}$ & $\mathbf{E P}$ & PMF & RD & WC & Average impact \\
\hline Design for reducing wastes & $30 \%$ & $33 \%$ & $33 \%$ & $48 \%$ & $23 \%$ & $32 \%$ & $33 \%$ \\
\hline Design for using renewable energies & $35 \%$ & $46 \%$ & $53 \%$ & $55 \%$ & $81 \%$ & $23 \%$ & $49 \%$ \\
\hline Design for reuse & $28 \%$ & $33 \%$ & $11 \%$ & $4 \%$ & $27 \%$ & $12 \%$ & $19 \%$ \\
\hline Design for remanufacturing & $27 \%$ & $26 \%$ & $32 \%$ & $31 \%$ & $37 \%$ & $23 \%$ & $29 \%$ \\
\hline Design for recycling & $94 \%$ & $71 \%$ & $63 \%$ & $144 \%$ & $78 \%$ & $76 \%$ & $88 \%$ \\
\hline Design for energy recovery & $28 \%$ & $35 \%$ & $30 \%$ & $19 \%$ & $39 \%$ & $27 \%$ & $30 \%$ \\
\hline Design for disposal & $32 \%$ & $42 \%$ & $23 \%$ & $38 \%$ & $43 \%$ & $29 \%$ & $34 \%$ \\
\hline Design for recovering energy from waste & $439 \%$ & $131 \%$ & $13 \%$ & $90 \%$ & $18 \%$ & $460 \%$ & $192 \%$ \\
\hline
\end{tabular}


Fig. 3 Percentage reductions of each environmental impact category associated with the two sub-strategies of Design for reducing waste

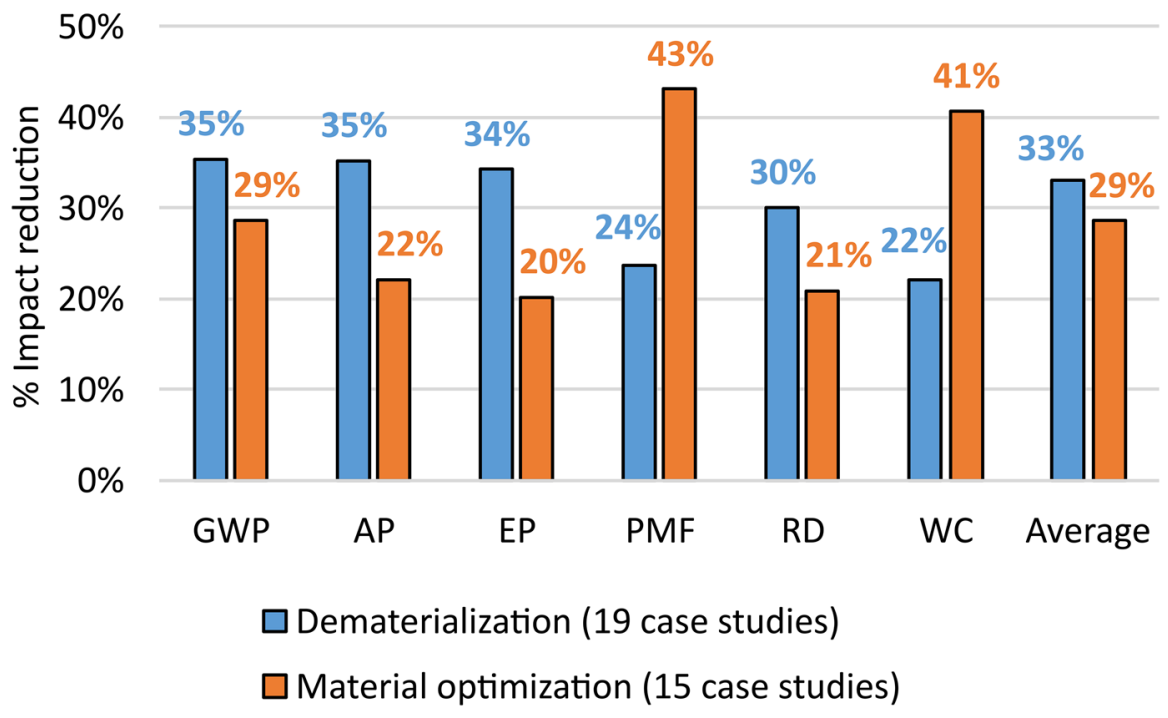

in percentage reduction of the impacts of the first category compared to the second one: Average impact (34\% vs. $28 \%$ ), GWP (37\% vs. $26 \%$ ), AP (35\% vs. $20 \%)$, EP ( $32 \%$ vs. $24 \%)$, PMF (39\% vs. $25 \%$ ) and RD (45\% vs. $7 \%$ ).

This result is also useful for providing experimental and quantitative evidences to Kemp (2010) considerations about the link between eco-innovation and environmental sustainability. In this work, the author discussed the environmental advantages guaranteed by the application of different innovation strategies to eliminate the produced wastes. While Bossink (2013) hypothesized that the rethinking of the functioning of a device can reduce the wastes by limiting the provided evidences only for some specific application fields.

\section{Design for using renewable energies}

The result associated with Design for using renewable energies confirmed the doubts raised by Horbach et al. (2015) about this strategy in implementing CE. Our study showed that the main strengths of this strategy are the reductions or RD and GWP. Both these reductions are primarily due to the use of solar and wind energy in large plants (e.g., Tannous et al., 2018; Yan et al., 2018), while, in smaller installations such as hydrogen-powered vehicles (e.g., Lajunen \& Lipman, 2016) and biogas production by anaerobic digestion activated by sun (e.g., Wu et al., 2020) the impact reductions associated with this strategy were lower. In the analysed case studies, the reason provided about this influence of the scale factor are the higher impacts of the realization of technologies for exploiting renewable energies compared to fossil-fuelled plants. Finally, the obtained result is fully with the work of Elia et al. (2017) which associated a significant role in the use of renewable energies in the CE only in energyintensive plants. However, that analysis excluded some environmental impact categories, including emissions to air, soil and water, material losses and resource depletion.

\section{Design for reuse}

Only the detailed analysis of all the case studies associated with Design for reuse explained why this strategy obtained modest results. When Design for reuse is associated with building materials (e.g. Rios et al., 2015) or mechanical components (e.g. Postacchini et al., 2018), reductions in environmental impacts are on average between 36 and $74 \%$. These values are therefore comparable or greater than Design for Recycling. However, the data extracted from some other case studies lowered the average reductions in all impact categories. The reason is the considerable amount of energy required to transport water to be reused, not present in freshwater systems. In these cases, the average environmental impact reduction is $17 \%$. This conclusion provides quantitative evidences to the more qualitative observations provided by Voulvoulis (2018).

\section{Design for remanufacturing}

The good results in reducing the environmental impacts in the case studies associated with Design for remanufacturing depend on the type of performed 
processing. This aspect clearly emerges by classifying the case study two sub-classes about conventional remanufacturing (14 case studies) and innovative remanufacturing (8 case studies), as shown in Fig. 4. Conventional remanufacturing mainly involves processes carried out with traditional machine tools for chip removal (e.g. Zhang \& Chen, 2015). While innovative remanufacturing is based on laser processing (e.g. Leino et al., 2016) or on additive manufacturing (e.g. Wilson et al., 2014) to allow more focused repairs by reducing filler material and energy consumption.

Figure 4 clearly shows the advantages of innovative remanufacturing over conventional remanufacturing in reducing environmental impacts, especially of AP, EP and PMF. On the other hand, the impact reduction of WC $(-34 \%)$ was against the trend and contributed to reduce the margin of advantage of the average impact (5\%). At the application level, the two ways of proceeding clearly influence the Design for remanufacturing, by providing different solutions depending on the two cases, in all five phases of this discipline, i.e. design for reverse channel, design for environment, design for dismantling, design for lifecycle extension, design for improvement and design for appraisal (Charter \& Gray, 2008). The results obtained with this classification provide quantitative evidence to the same theoretical comparison, previously discussed in Singhal et al. (2020).

\section{Design for recycling}

By classifying the case studies associated with Design for recycling in the two sub-strategies about ecosystem restoration (17 case studies) (Cherubini et al., 2015) and technical recycling (10 case studies) (Bertolini et al., 2016) (see Fig. 5), described in "Tested design strategies for circular economy", the reasons of the results of this strategy can be comprehended.

Figure 5 shows that ecosystem restoration is, on average, better than technical recycling, which, however, allows a good average reduction of environmental impacts (i.e. 47\%). The main advantages of the first sub-strategy, compared to the second, were found above all regarding AP $(+50 \%), \mathrm{RD}(+21 \%)$ and PMF $(+8 \%)$. From the analysis of the case studies emerged the role of the recycling process. Both the sub-strategies are convenient for environmental sustainability, avoiding the introduction of virgin materials, but the technical recycling processes are generally more impactful than the others. This is because, in the second case, a more radical transformation of the waste, and also more energy-intensive, is required (e.g. de Souza Junior et al., 2020; Pintilie et al., 2016). However, this result is partial, because some authors in the literature (e.g. Convertino et al., 2013) highlighted other parameter to consider (e.g. local species richness, river basin extension, hydroperiod). Therefore, the provided assessment is starting point to be integrated with a more comprehensive analysis, even if still lacking in the literature.

\section{Design for energy recovery}

To discuss the results that have been associated with Design for energy recovery in this study, a further subdivision between systems that propose pure
Fig. 4 Percentage reductions of each environmental impact category associated with the two sub-strategies of Design for remanufacturing

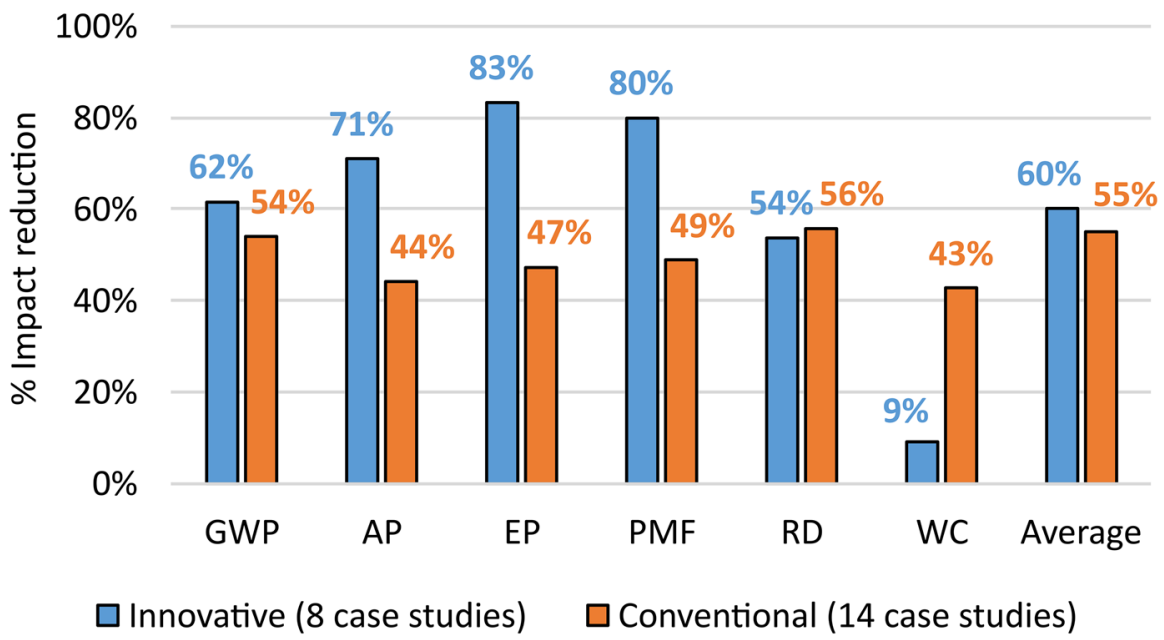


Fig. 5 Percentage reductions of each environmental impact category associated with the two sub-strategies of Design for recycling

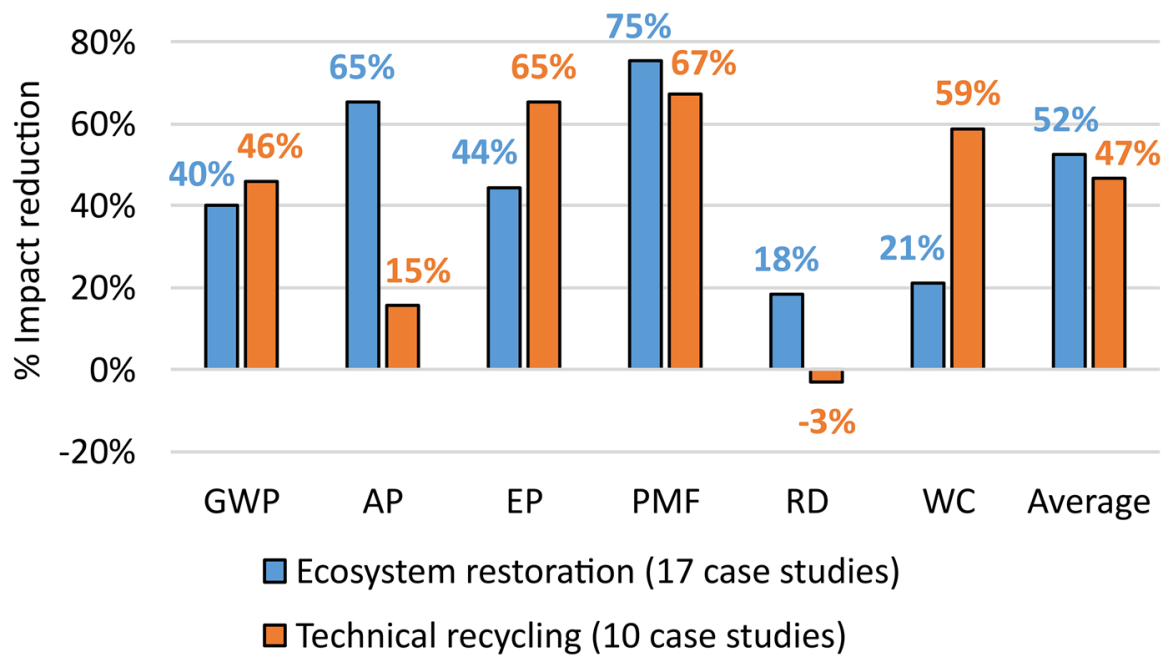

energy recovery (6 case studies) (e.g. Feng et al., 2014) from those that also introduce phase transition (13 case studies) (e.g. Cánovas et al., 2013) was provided (see Fig. 6).

Through the classification, both the sub-strategies were found to be beneficial for all the environmental impact categories (see Fig. 6). In addition, the phase transition in energy recovery was better for GWP, EP and RD. This result is useful for extending the advantages of this sub-strategy in environmental sustainability, previously provided by Spreafico (2021) also to implement CE. Liu et al. (2019), Boavida et al. (2020) and Vinodh et al. (2014) sustained the same conclusions but without supporting it with the assessment of the impacts trough standard categories, while Ozkeser
(2018) limited the assessment to the GWP. However, in all these studies, the proposed evaluation is too aggregated, since different inventive principles are considered altogether and the considered case studies are few and too specific.

\section{Design for disposal}

To adequately discuss the results obtained for the Design of disposal, the case studies referring to this strategy were further divided into its two sub-strategies, i.e. using natural materials (14 case studies) (e.g. Liu et al., 2019) and using natural-based materials (8 case studies) (e.g. Razza et al., 2015). The reductions
Fig. 6 Percentage reductions of each environmental impact category associated with the two sub-strategies of Design for energy recovery

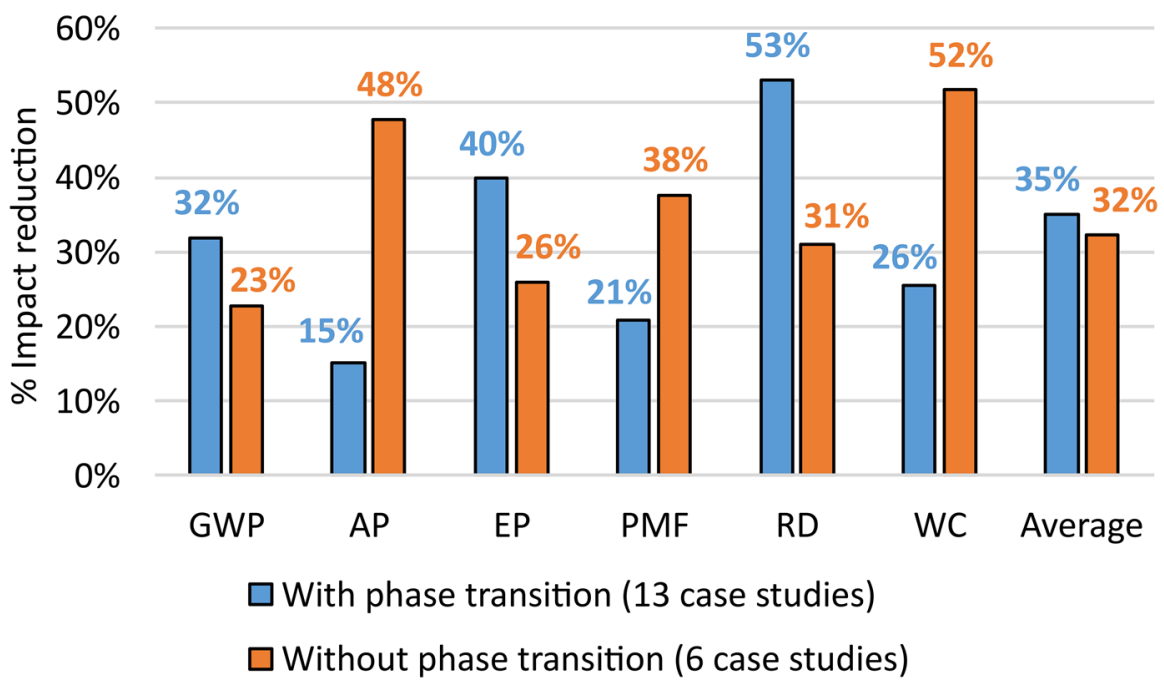


in environmental impacts associated with these two sub-strategies were determined and reported in Fig. 7.

The distinction between the sub-strategies proved to be useful for better understanding the relationships between Design for disposal and the resulting reduction in environmental impacts (see Fig. 7). The greatest environmental advantages associated with this strategy were obtained in the case studies where natural materials have been introduced. They proved to be more sustainable than natural-based materials in reducing the average impact $(+31 \%)$ and in almost all impact categories, except GWP (-5\%), EP (-13\%) and RD (-2\%). In addition, the negative result obtained by naturalbased material in WC $(-54 \%)$ was also highlighted.

These results therefore confirm on a quantitative level some observations that have been made in the literature about the sustainability of the disposal of natural-based materials and to the tendency to prefer materials as natural as possible during this phase, although these observations are based on restricted application fields. For example, Hottle et al. (2013), with a review of LCA studies on bio-polymers, show that such materials are sustainable during production, while during disposal have some impacts similar to synthetic polymers. The conclusion is therefore to prefer biodegradable materials. This trend is recently being sought in food packaging, both for the realization of the packaging with natural materials such as chitosan, and with the increasing use of vegetable oils and acids as bactericides (Spreafico \& Russo, 2021). Another field of application is in the construction of asphalts for road repair, where the use of unprocessed natural materials such as gravel and rocks in larger portions and the limitation of natural-based materials to targeted infill during maintenance are preferred (Landi et al., 2020).

Design for recovering energy from waste

The results associated with this strategy confirmed the advantages of the implementation of $\mathrm{CE}$ and the research about the supporting design strategies. The analysis of the considered case studies also showed that the result does not change much when discriminating between different types of waste treatment. Pyrolysis (e.g., Vocciante et al., 2019) environmentally performed better than traditional incineration (e.g., Hossain \& Poon, 2018), although the latter is significantly more widespread worldwide (Spreafico et al., 2021). The alternating results for the different impact categories of this strategy (see Fig. 2) show that there are some advantages for certain impact categories but their quantities nor comparable with the other CE options.

Final considerations

In order to provide a further term of evaluation of the Design strategies for CE, Table 2 reports the standard deviations associated with the percentage reductions of the environmental impact categories for their derived sub-strategies, which average impact reductions as reported in Figs. 3, 4, 5, 6, and 7.
Fig. 7 Percentage reductions of each environmental impact category associated with the two sub-strategies of Design for disposal




Table 2 Standard deviations associated with the percentage reductions of the environmental impact categories of the sub-strategies of the considered Design strategies for CE

\begin{tabular}{|c|c|c|c|c|c|c|c|c|}
\hline CE options & Design strategies & GWP & $\mathbf{A P}$ & EP & PMF & RD & WC & Average \\
\hline \multirow[t]{2}{*}{ Design for reducing wastes } & Dematerialization & $31 \%$ & $35 \%$ & $29 \%$ & $61 \%$ & $25 \%$ & $34 \%$ & $33 \%$ \\
\hline & Material optimization & $30 \%$ & $31 \%$ & $37 \%$ & $18 \%$ & $20 \%$ & $30 \%$ & $28 \%$ \\
\hline \multirow[t]{2}{*}{ Design for remanufacturing } & Innovative & $24 \%$ & $13 \%$ & $9 \%$ & $8 \%$ & $11 \%$ & $21 \%$ & $24 \%$ \\
\hline & Conventional & $29 \%$ & $26 \%$ & $33 \%$ & $38 \%$ & $41 \%$ & $25 \%$ & $24 \%$ \\
\hline \multirow[t]{2}{*}{ Design for recycling } & Ecosystem restoration & $100 \%$ & $68 \%$ & $21 \%$ & $138 \%$ & $30 \%$ & $73 \%$ & $72 \%$ \\
\hline & Technical recycling & $90 \%$ & $68 \%$ & $72 \%$ & $159 \%$ & $105 \%$ & $88 \%$ & $81 \%$ \\
\hline \multirow[t]{2}{*}{ Design for energy recovery } & With phase transition & $27 \%$ & $26 \%$ & $32 \%$ & $23 \%$ & $46 \%$ & $29 \%$ & $28 \%$ \\
\hline & Without phase transition & $31 \%$ & $40 \%$ & $32 \%$ & $13 \%$ & $40 \%$ & $20 \%$ & $29 \%$ \\
\hline \multirow[t]{2}{*}{ Design for disposal } & Natural materials & $34 \%$ & $46 \%$ & $21 \%$ & $33 \%$ & $21 \%$ & $37 \%$ & $39 \%$ \\
\hline & Natural-based materials & $31 \%$ & $17 \%$ & $26 \%$ & $39 \%$ & $18 \%$ & $28 \%$ & $21 \%$ \\
\hline
\end{tabular}

On the other hand, Fig. 8 shows the result of the economic evaluation of the considered Design strategies for CE. For each of them, the average of the percentage reduction in the costs of the solutions obtained by their application compared to the baseline options is reported.

The result shown in Fig. 8 suffers from a major limitation compared to those relating to environmental impacts in Figs. 1, 2, 3, 4, 5, 6, and 7, i.e. the smaller number of considered case studies. This is because only a part of the considered articles also provides economic considerations. Consequently, the results associated with some strategies are based on a statistically insignificant number of sources (i.e. even fewer than three articles). In light of such limitations, this result should not therefore be used to compare the different strategies, ranking them on the basis of economic convenience. It is instead a confirmation also of the increased economic sustainability, as well as environmental, of the solutions associated with considered Design strategies for CE, compared to the other solutions.

Table 3 summarizes the observations that emerged from the discussion of the results obtained for all tested Design strategies for CE, shown in "Design for reducing wastes", "Design for using renewable energies", "Design for reuse", "Design for remanufacturing", "Design for recycling", "Design for energy recovery", "Design for disposal" and "Design for recovering energy from waste". For each strategy, the advantages and the disadvantages for environmental sustainability were reported, i.e. how they were applied to achieve the greatest and least average reductions in environmental impacts, respectively, compared to the baseline scenario.
Fig. 8 Percentage impact reductions of the average cost associated with each design (D.) strategy for CE resulted from the analysis of the considered case studies (c.s.)

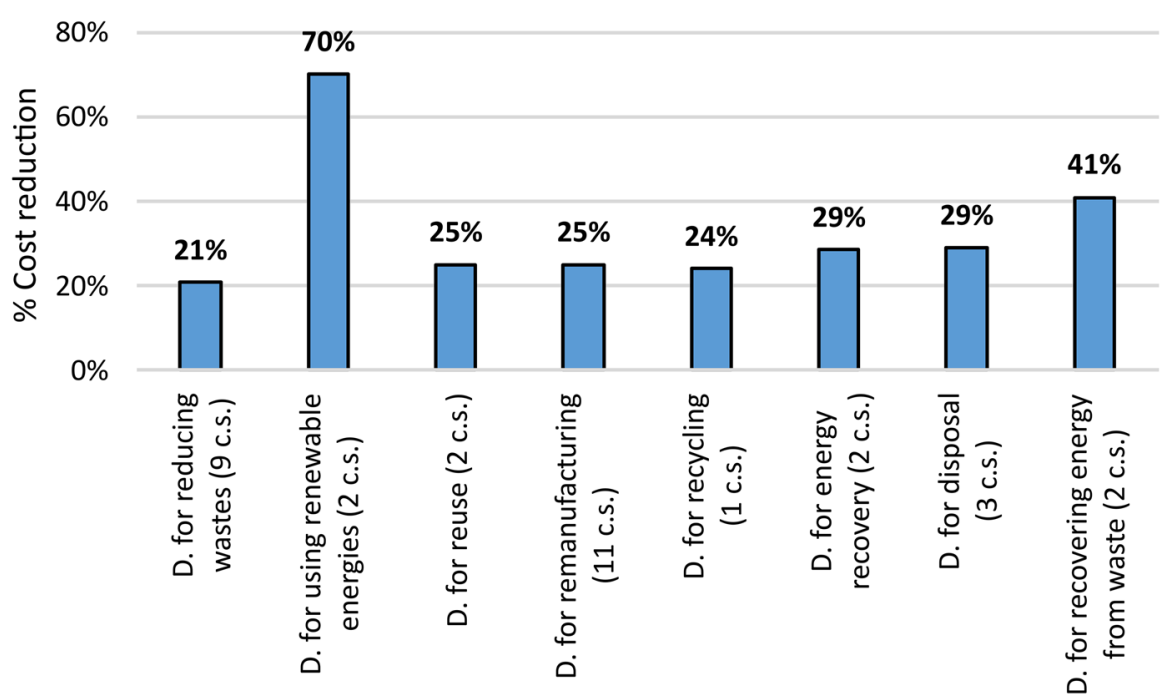


Table 3 Summary of the advantages and disadvantages of applying Design strategies for CE in the considered case studies

\begin{tabular}{|c|c|c|}
\hline Design strategies for $\mathbf{C E}$ & Advantages (good for) & Disadvantages (less good for) \\
\hline Design for reducing wastes & $\begin{array}{l}\text { - Dematerialization } \\
\text { - Changing the physical principle of opera- } \\
\text { tion of the system }\end{array}$ & $\begin{array}{l}\text { - Material optimization, in particular struc- } \\
\text { tural optimization which was less sustain- } \\
\text { able than fluid dynamic optimization } \\
\text { - Keeping the physical principle of operation } \\
\text { of the system unchanged }\end{array}$ \\
\hline Design for using renewable energies & $\begin{array}{l}\text { Supplying large plants with renewable } \\
\text { energies, in order to compensate for the } \\
\text { environmental impacts deriving from the } \\
\text { introduction of dedicated technologies }\end{array}$ & $\begin{array}{l}\text { Supplying small plants with renewable ener- } \\
\text { gies }\end{array}$ \\
\hline Design for reuse & $\begin{array}{l}\text { Reusing mechanical products and compo- } \\
\text { nents }\end{array}$ & Reusing natural resources (i.e. wastewater) \\
\hline Design for remanufacturing & $\begin{array}{l}\text { Using non-conventional techniques (e.g. } \\
\text { laser) }\end{array}$ & $\begin{array}{l}\text { Using conventional techniques (e.g. chip } \\
\text { removal) }\end{array}$ \\
\hline Design for recycling & Ecosystem restoration & Technical recycling \\
\hline Design for energy recovery & Phase transition & Heat exchanger without phase transition \\
\hline Design for disposal & Natural materials & Natural-based materials (e.g. bio-polymers) \\
\hline Waste to energy & Pyrolysis & Incineration \\
\hline
\end{tabular}

Perspectives and prospects

The results of this study can serve as a basis for some future research directions. The fact of having questioned the more common hierarchy of CE options, by introducing new categories of environmental impact, should be studied in greater depth. On the one hand, it could be useful to investigate the relationships between the $\mathrm{CE}$ options and the types of environmental impacts, by identifying which operations, necessary to implement a CE option, have the highest impacts, why and in what way. On the other hand, it is necessary to compare the hierarchy of the CE options with a hierarchy of importance of the categories of environmental impact, in order to confirm or reject the first one through a more reliable indicator, e.g. by using a weighted mean.

Furthermore, the heterogeneity of the evaluations of the CE options in relation to the characteristics of the product and the application field can be better formalized. In this case, the product requirements could be formalized in a more rigorous manner, for instance by using a systematic approach for their classification, such as Quality Function Deployment. Finally, a broader development that requires a deeper understanding of these issues could be the development of a design framework to suggest which design strategies could be applied to implement a CE option in a certain product with specific requirements, to guarantee, at the same time, the environmental sustainability.

\section{Conclusions}

This study proposed the eco-assessment of some common design strategies to implement some CE options, by manually analysing 156 case studies of Comparative LCA from selected scientific articles. The results are the percentage reductions of different standard impact categories compared to baseline scenarios where CE is not implemented. The main limitations of this study concern the analysed case studies, which although in large numbers belong only to certain application areas. In addition, the number of considered case studies decreased notably for certain stratifications, e.g. by comparing the different design strategies referring to a CE option.

Through the obtained results, it was possible to hierarchize the design strategies for improving the environmental sustainability (RQ. 1), although the emerged hierarchy differs from that provided by some other studies. Considering the average of all impact categories, Design for remanufacturing produced the best options with impact reductions by $53 \%$, followed by Design for recycling (45\%), while Design for recovering energy from waste was the worst option, increasing the impacts by $83 \%$. Considering instead the different impact categories, a certain variability emerged, as well as between the results of the different case studies and those within the Design strategies (with standard deviations between 21 and $81 \%$ ). 


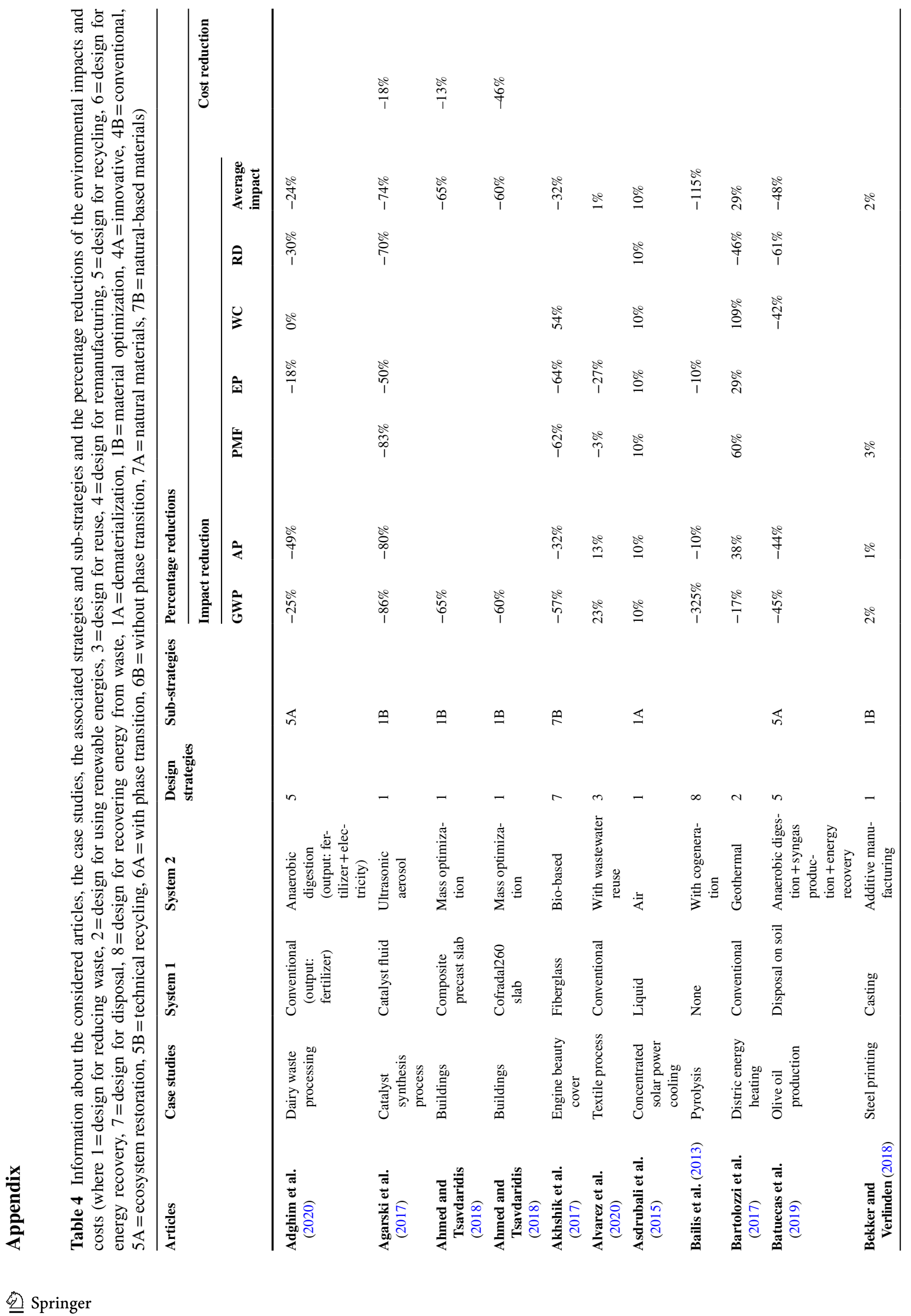




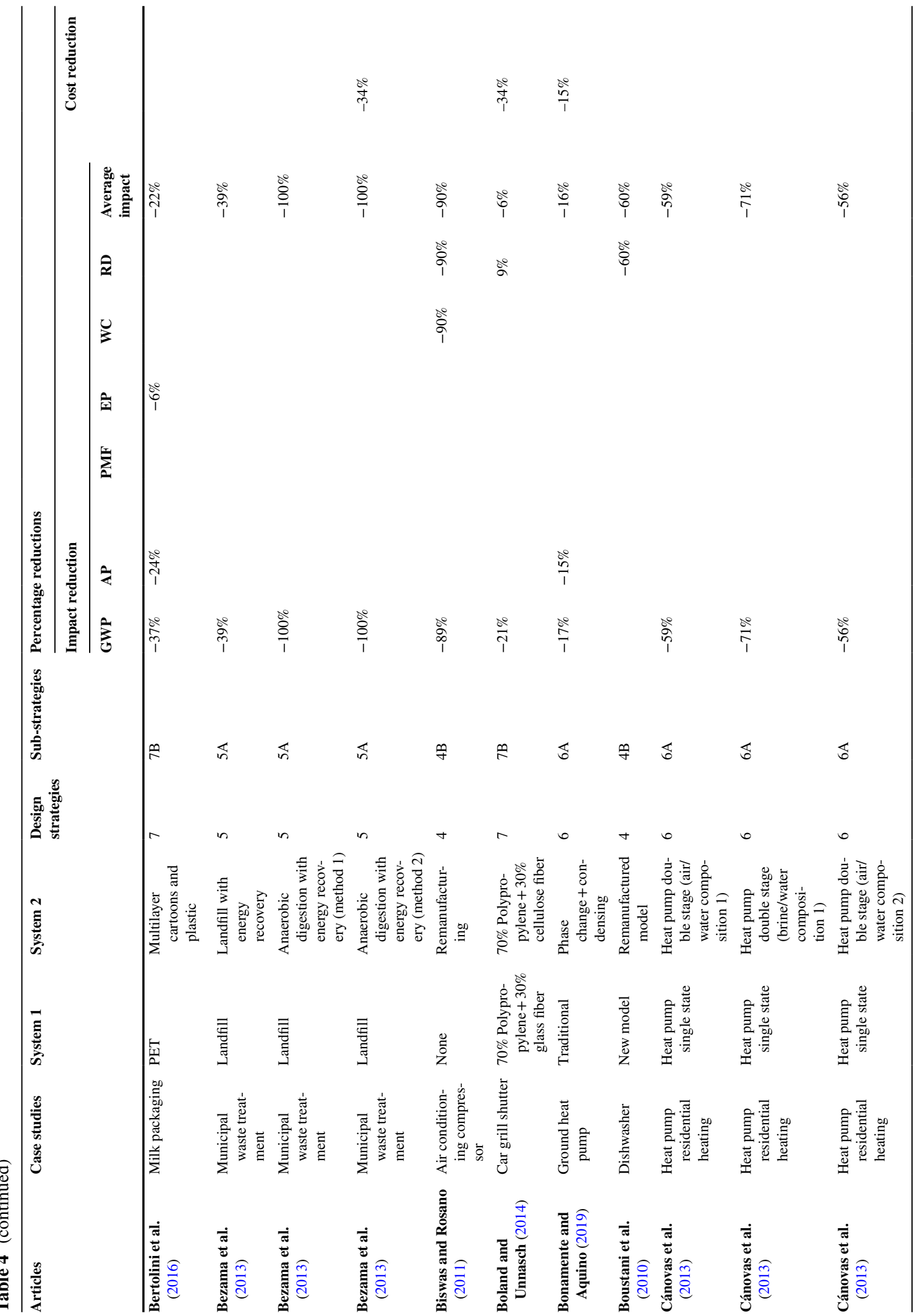




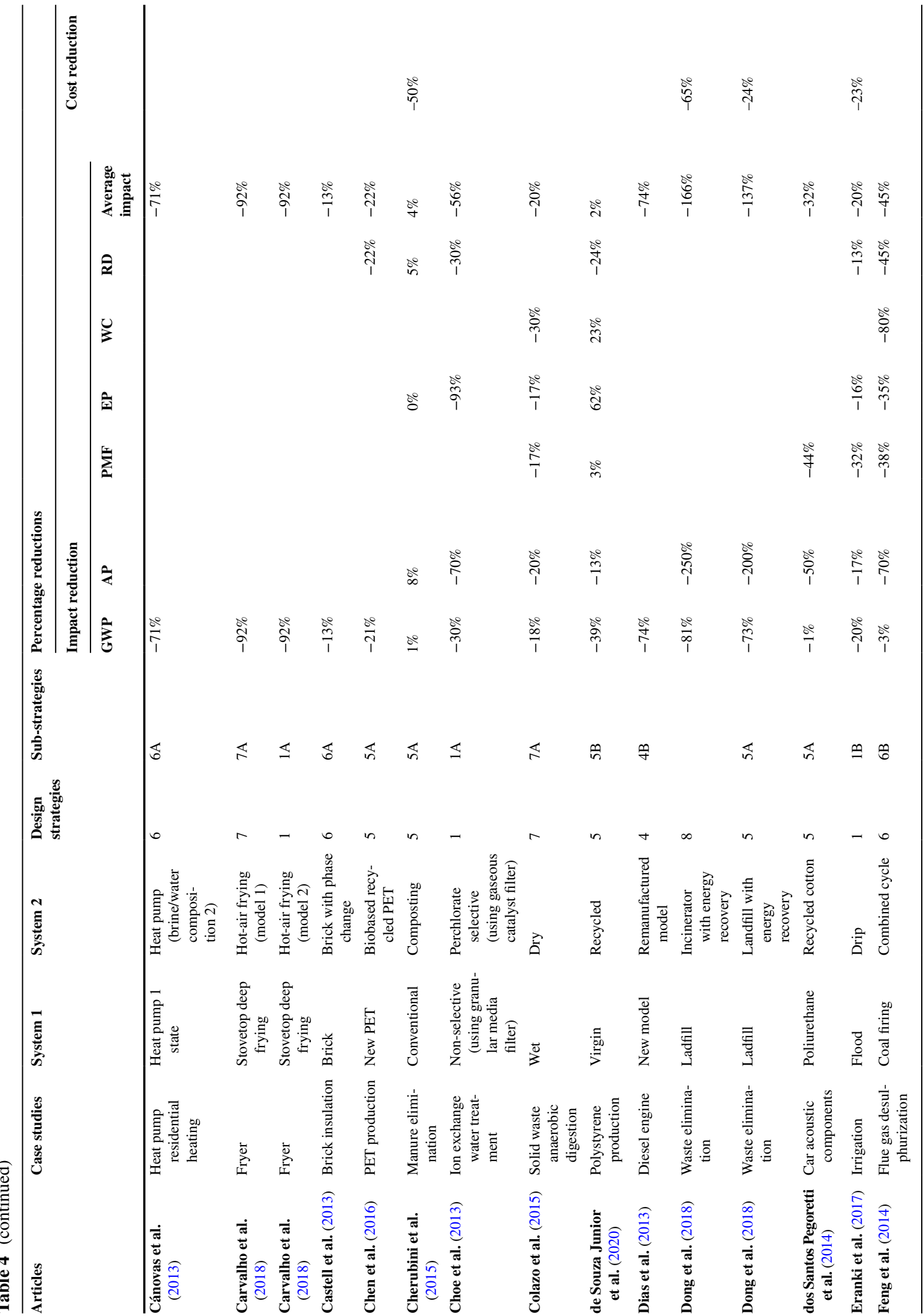




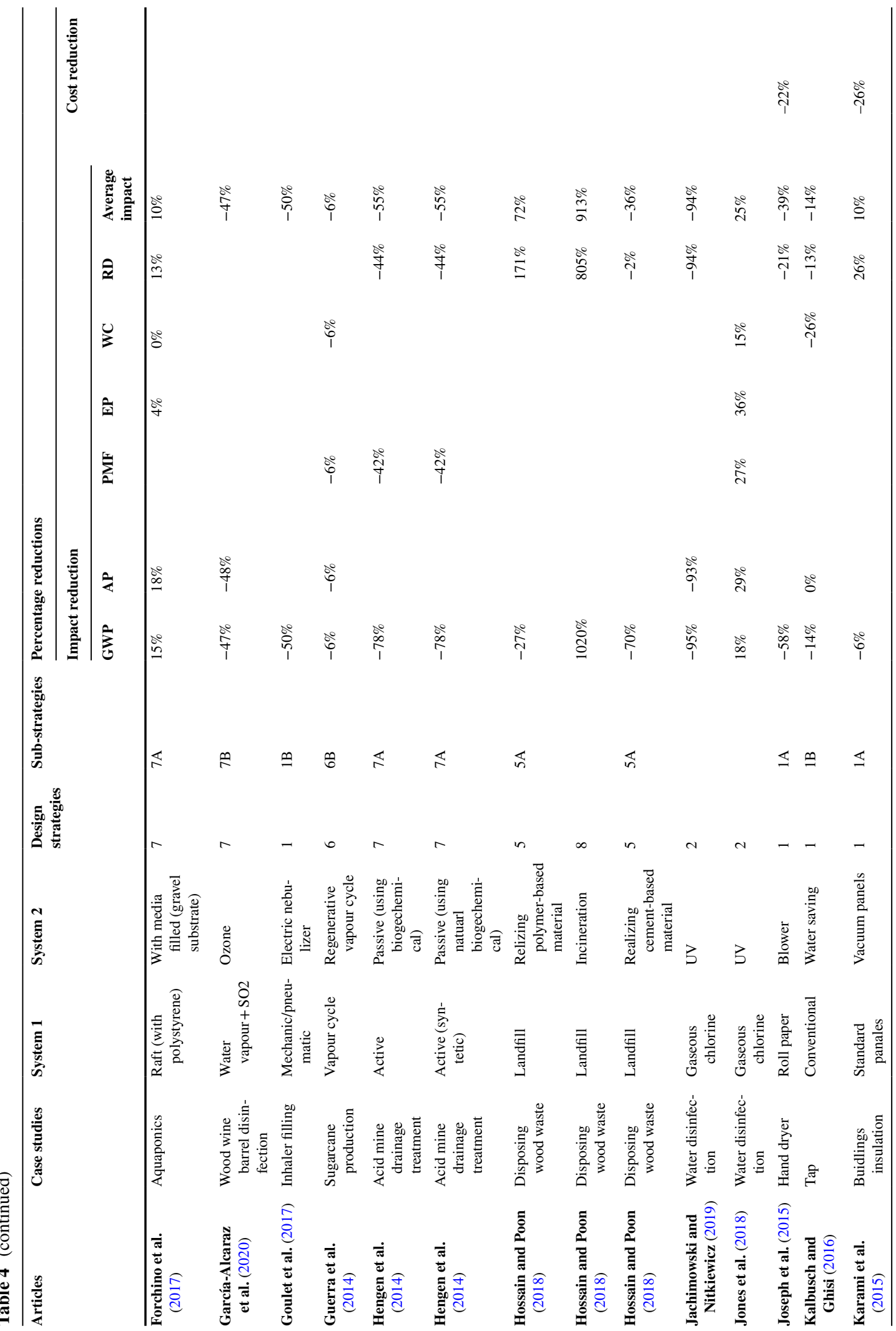




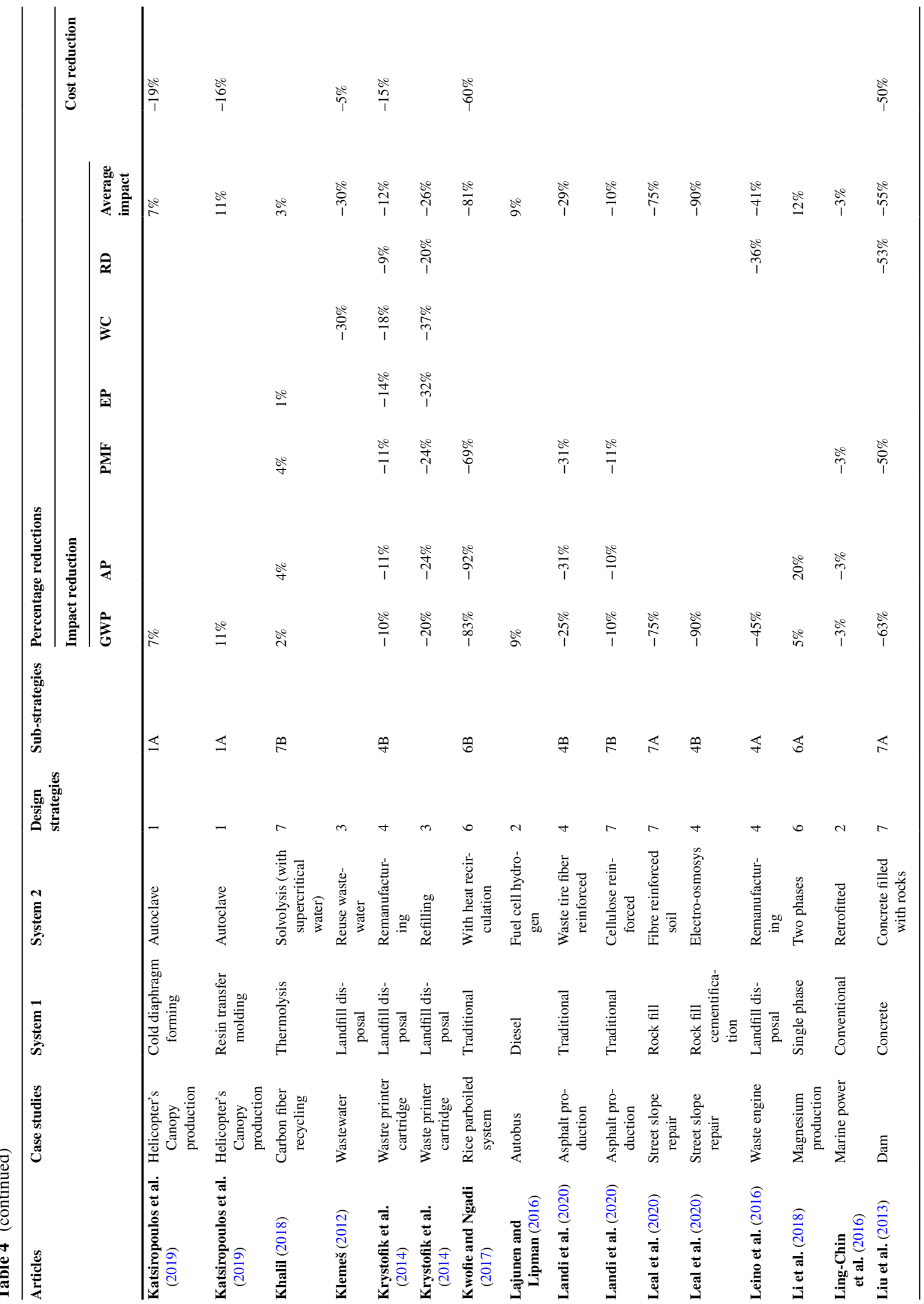




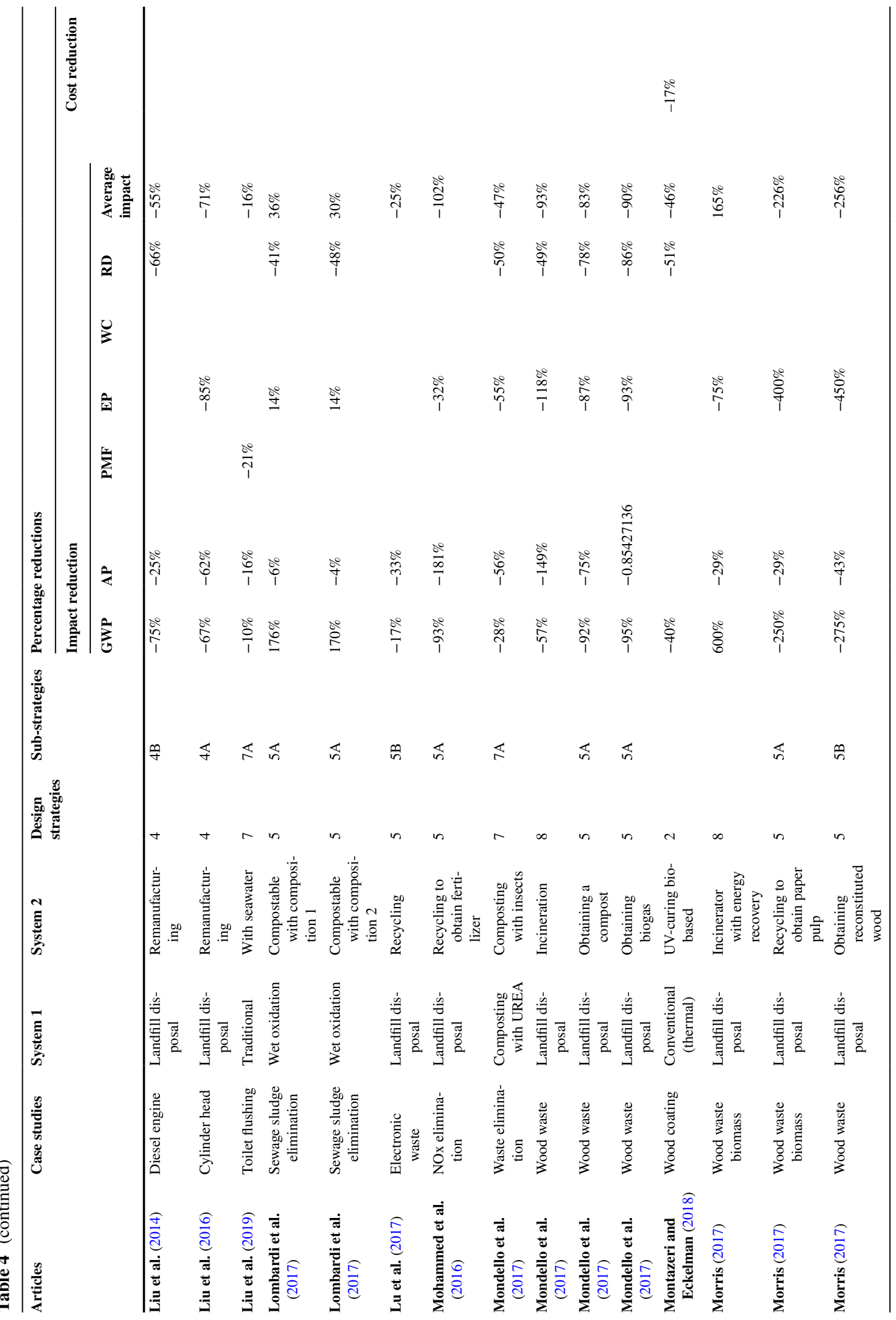




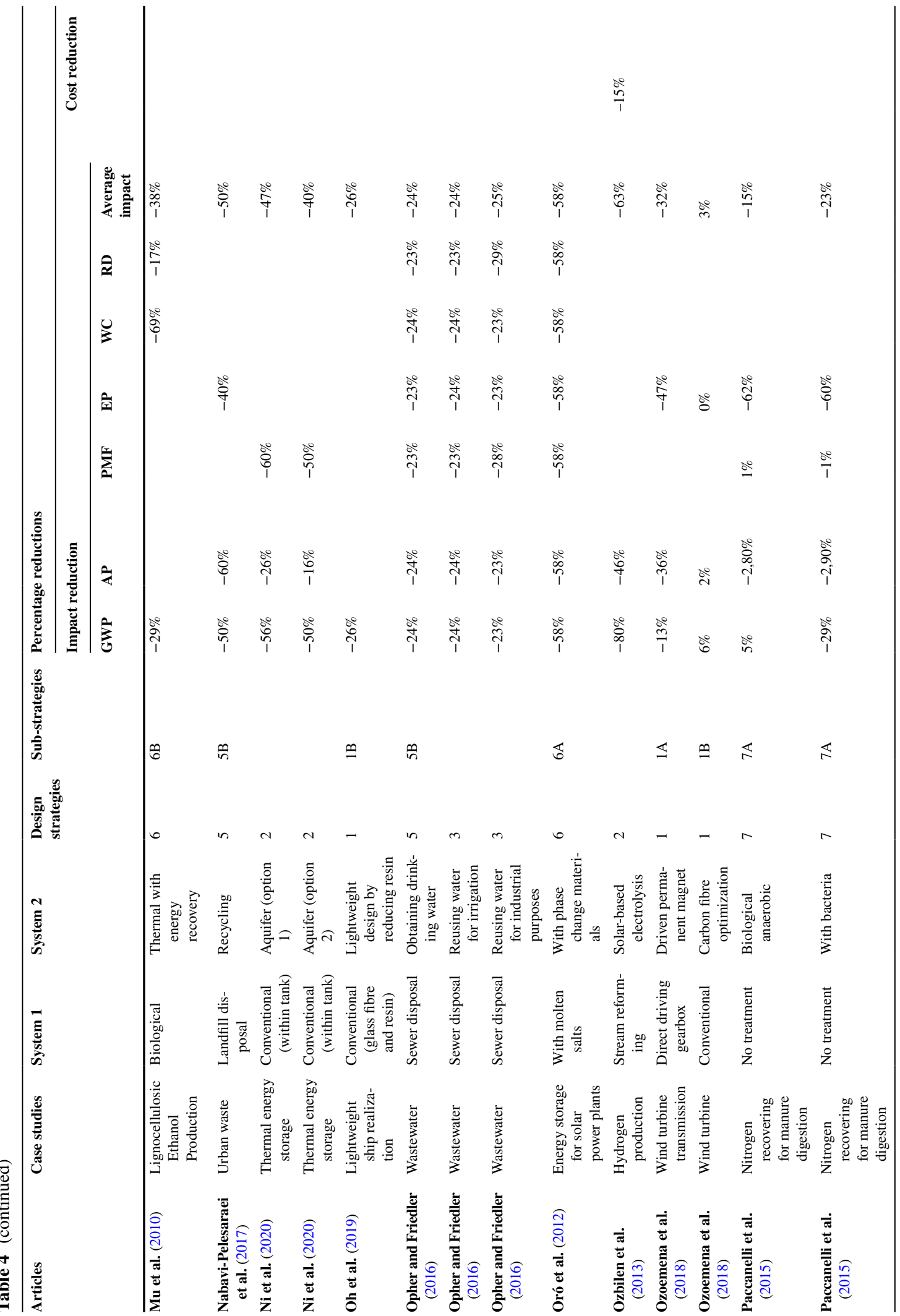




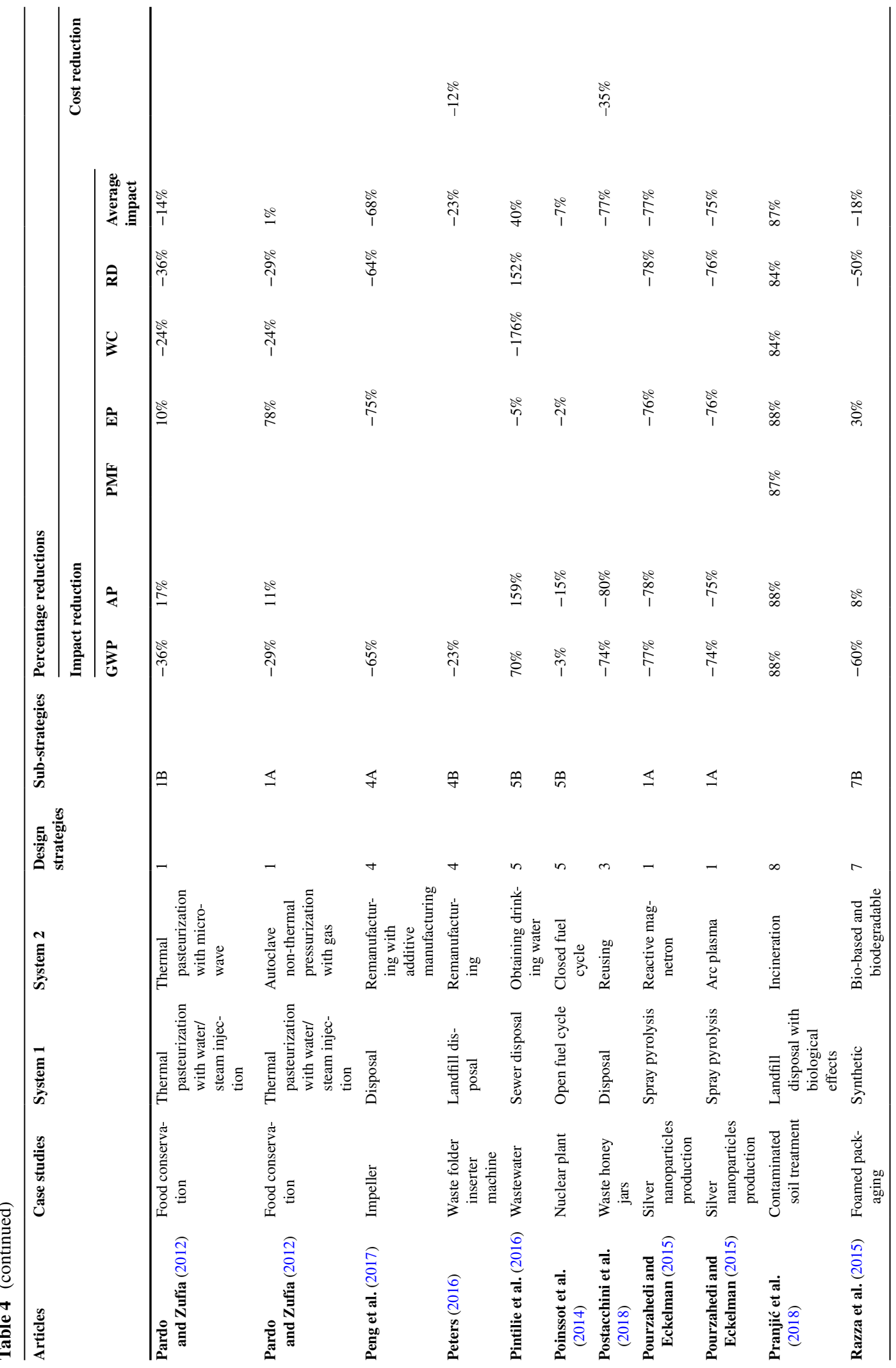




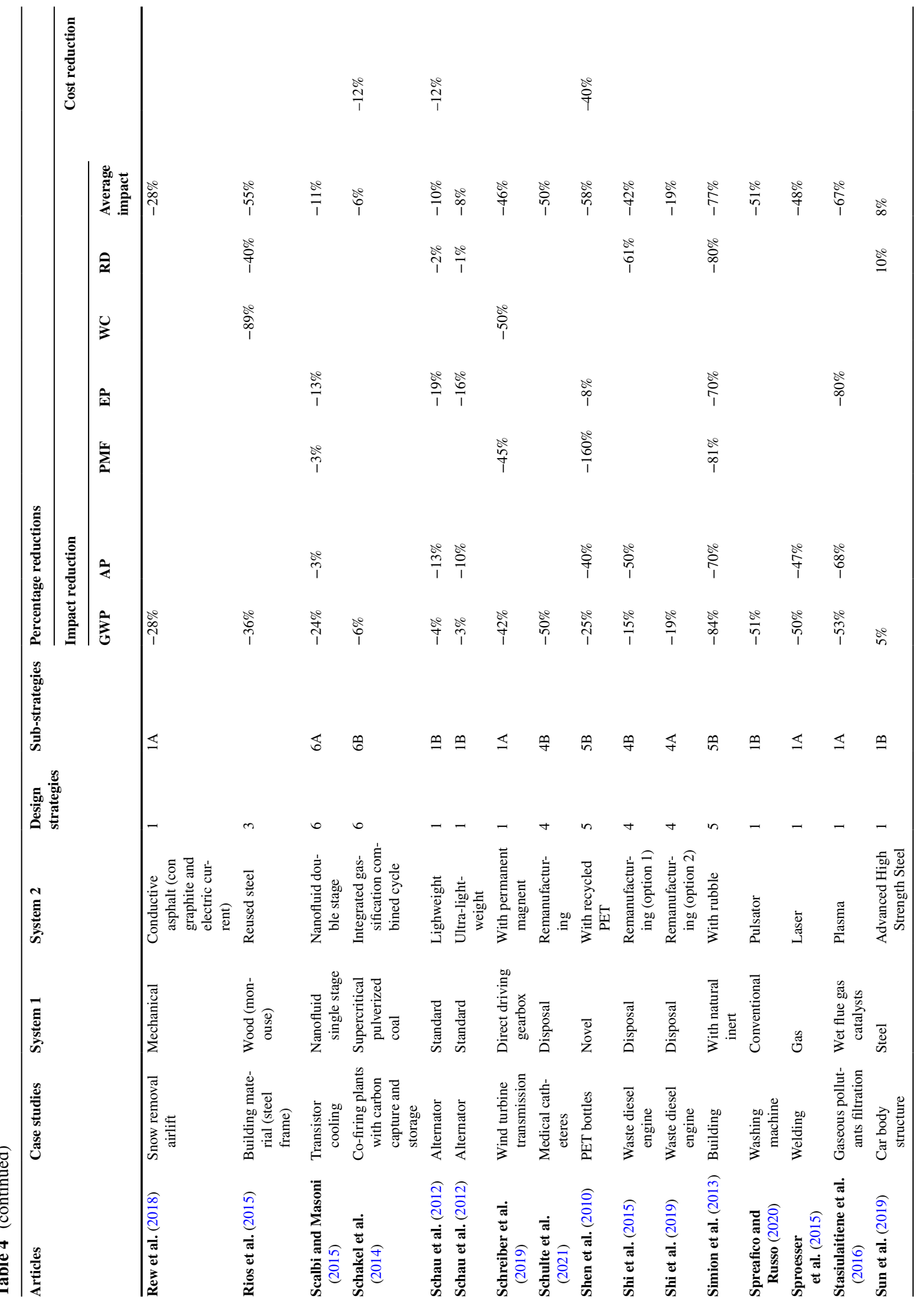




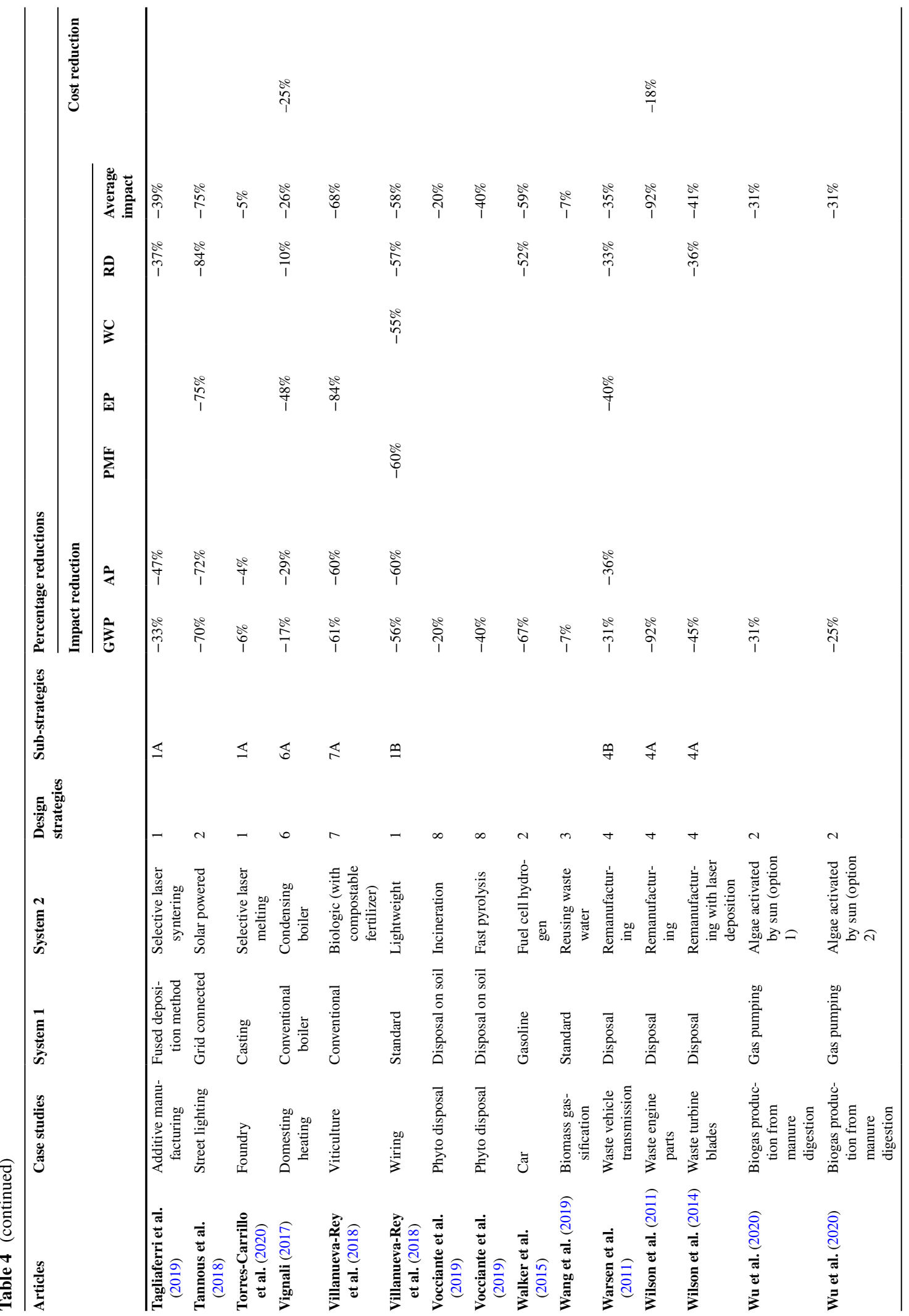




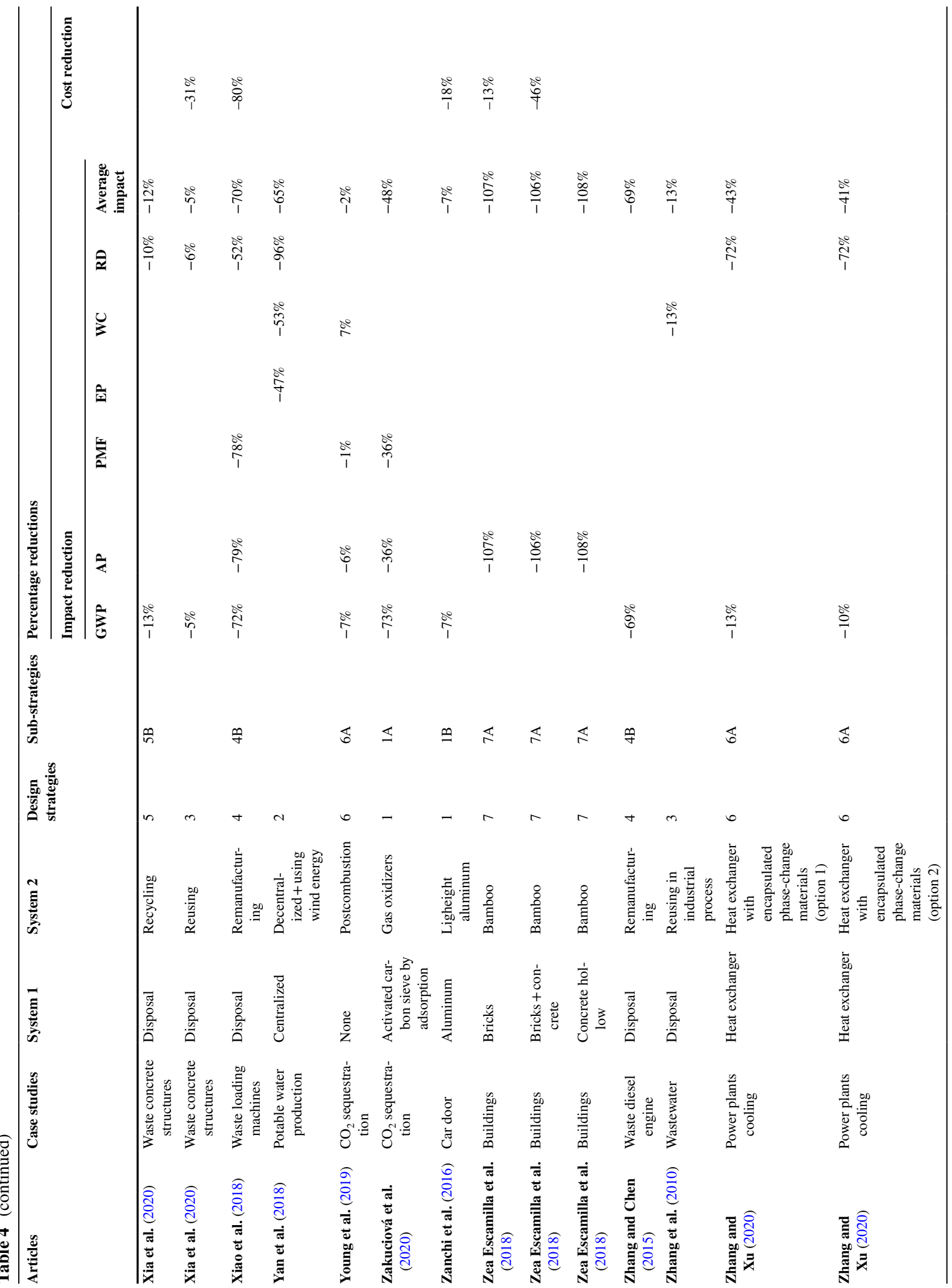


Finally, the economic sustainability of the solutions arising from the Design strategies for CE is also considered, although considering a smaller number of case studies.

Nevertheless, by deeply analysing the considered case studies, some motivations for the advantages and disadvantages for environmental sustainability of the different Design strategies for CE were also identified. They depend by the specific characteristics of the products and the application fields, thus confirming RQ. 2.

Data availability The datasets generated during and/or analysed during the current study are available from the corresponding author on reasonable request.

\section{Declarations}

Conflict of interest The author declares no competing interests.

Open Access This article is licensed under a Creative Commons Attribution 4.0 International License, which permits use, sharing, adaptation, distribution and reproduction in any medium or format, as long as you give appropriate credit to the original author(s) and the source, provide a link to the Creative Commons licence, and indicate if changes were made. The images or other third party material in this article are included in the article's Creative Commons licence, unless indicated otherwise in a credit line to the material. If material is not included in the article's Creative Commons licence and your intended use is not permitted by statutory regulation or exceeds the permitted use, you will need to obtain permission directly from the copyright holder. To view a copy of this licence, visit http://creativecommons.org/licenses/by/4.0/.

\section{References}

Agarski, B., Nikolić, V., Kamberović, Ž, Anđić, Z., Kosec, B., \& Budak, I. (2017). Comparative life cycle assessment of $\mathrm{Ni}$-based catalyst synthesis processes. Journal of Cleaner Production, 162, 7-15.

Adghim, M., Abdallah, M., Saad, S., Shanableh, A., Sartaj, M., \& El Mansouri, A. E. (2020). Comparative life cycle assessment of anaerobic co-digestion for dairy waste management in large-scale farms. Journal of Cleaner Production, 256, 120320.

Ahmed, I. M., \& Tsavdaridis, K. D. (2018). Life cycle assessment (LCA) and cost (LCC) studies of lightweight composite flooring systems. Journal of Building Engineering, 20, 624-633.

Akhshik, M., Panthapulakkal, S., Tjong, J., \& Sain, M. (2017). Life cycle assessment and cost analysis of hybrid fiberreinforced engine beauty cover in comparison with glass 
fiber-reinforced counterpart. Environmental Impact Assessment Review, 65, 111-117.

Altshuller, G. S. (1984). Creativity as an exact science: The theory of the solution of inventive problems. Gordon and Breach

Alvarez, M. D., Buscio, V., Lopez-Grimau, V., \& GutierrezBouzan, C. (2020). LCA study of a new electrochemical and ultraviolet (EC-UV) combined system to decolourise and reuse textile saline effluents: Environmental evaluation and proposal to improve the production process. Chemical Engineering Journal, 392, 123696.

Amponsah, N. Y., Lacarrière, B., Jamali-Zghal, N., \& Le Corre, O. (2012). Impact of building material recycle or reuse on selected emergy ratios. Resources, Conservation and Recycling, 67, 9-17.

Asdrubali, F., Baldinelli, G., D’Alessandro, F., \& Scrucca, F. (2015). Life cycle assessment of electricity production from renewable energies: Review and results harmonization. Renewable and Sustainable Energy Reviews, 42, 1113-1122.

Bailis, R., Rujanavech, C., Dwivedi, P., de Oliveira Vilela, A., Chang, H., \& de Miranda, R. C. (2013). Innovation in charcoal production: a comparative life-cycle assessment of two kiln technologies in Brazil. Energy for Sustainable Development, 17(2), 189-200.

Bartolozzi, I., Rizzi, F., \& Frey, M. (2017). Are district heating systems and renewable energy sources always an environmental win-win solution? A life cycle assessment case study in Tuscany, Italy. Renewable and Sustainable Energy Reviews, 80, 408-420.

Batuecas, E., Tommasi, T., Battista, F., Negro, V., Sonetti, G., Viotti, P., \& Mancini, G. (2019). Life Cycle Assessment of waste disposal from olive oil production: Anaerobic digestion and conventional disposal on soil. Journal of Environmental Management, 237, 94-102.

Behrens, A., Giljum, S., Kovanda, J., \& Niza, S. (2007). The material basis of the global economy: Worldwide patterns of natural resource extraction and their implications for sustainable resource use policies. Ecological Economics, 64(2), 444-453.

Bekker, A. C., \& Verlinden, J. C. (2018). Life cycle assessment of wire+ arc additive manufacturing compared to green sand casting and CNC milling in stainless steel. Journal of Cleaner Production, 177, 438-447.

Bersano, G., Fayemi, P. E., Schoefer, M., \& Spreafico, C. (2017). An eco-design methodology based on a-LCA and TRIZ. In International Conference on Sustainable Design and Manufacturing (pp. 919-928). Springer, Cham.

Bertolini, M., Bottani, E., Vignali, G., \& Volpi, A. (2016). Comparative life cycle assessment of packaging systems for extended shelf life milk. Packaging Technology and Science, 29(10), 525-546.

Bezama, A., Douglas, C., Méndez, J., Szarka, N., Muñoz, E., Navia, R., \& Ulloa, C. (2013). Life cycle comparison of waste-to-energy alternatives for municipal waste treatment in Chilean Patagonia. Waste Management \& Research, 31(10_suppl), 67-74.

Biswas, W., \& Rosano, M. (2011). A life cycle greenhouse gas assessment of remanufactured refrigeration and air conditioning compressors. International Journal of Sustainable Manufacturing, 2(2-3), 222-236.
Boavida, R., Navas, H., Godina, R., Carvalho, H., \& Hasegawa, H. (2020). A combined use of TRIZ methodology and eco-compass tool as a sustainable innovation model. Applied Sciences, 10(10), 3535.

Bocken, N. M., De Pauw, I., Bakker, C., \& Van Der Grinten, B. (2016). Product design and business model strategies for a circular economy. Journal of Industrial and Production Engineering, 33(5), 308-320.

Boland, S., \& Unnasch, S. (2014). Carbon intensity of marginal petroleum and corn ethanol fuels. Life Cycle Associates Report LCA, 6075(83), 2014.

Bonamente, E., \& Aquino, A. (2019). Environmental performance of innovative ground-source heat pumps with PCM energy storage. Energies, 13(1), 1-1.

Bossink, B. (2013). Eco-innovation and sustainability management. Routledge.

Boustani, A., Sahni, S., Graves, S. C., \& Gutowski, T. G. (2010). Appliance remanufacturing and life cycle energy and economic savings. In Proceedings of the 2010 IEEE International Symposium on Sustainable Systems and Technology (pp. 1-6). IEEE.

Cai, G., \& Waldmann, D. (2019). A material and component bank to facilitate material recycling and component reuse for a sustainable construction: Concept and preliminary study. Clean Technologies and Environmental Policy, 21(10), 2015-2032.

Cánovas, A., Zah, R., \& Gassó, S. (2013). Comparative lifecycle assessment of residential heating systems, focused on solid oxide fuel cells. In Sustainability in Energy and Buildings (pp. 659-668). Springer, Berlin, Heidelberg.

Carvalho, M., Grilo, M. M. D. S., \& Abrahao, R. (2018). Comparison of greenhouse gas emissions relative to two frying processes for homemade potato chips. Environmental Progress \& Sustainable Energy, 37(1), 481-487.

Cayzer, S., Griffiths, P., \& Beghetto, V. (2017). Design of indicators for measuring product performance in the circular economy. International Journal of Sustainable Engineering, 10(4-5), 289-298.

Castell, A., Menoufi, K., De Gracia, A., Rincón, L., Boer, D., \& Cabeza, L. F. (2013). Life cycle assessment of alveolar brick construction system incorporating phase change materials (PCMs). Applied Energy, 101, 600-608.

Charter, M., \& Gray, C. (2008). Remanufacturing and product design. International Journal of Product Development, 6(3-4), 375-392.

Chen, L., Pelton, R. E., \& Smith, T. M. (2016). Comparative life cycle assessment of fossil and bio-based polyethylene terephthalate (PET) bottles. Journal of Cleaner Production, 137, 667-676.

Cherubini, E., Zanghelini, G. M., Alvarenga, R. A. F., Franco, D., \& Soares, S. R. (2015). Life cycle assessment of swine production in Brazil: a comparison of four manure management systems. Journal of Cleaner Production, $87,68-77$.

Cheshmehzangi, A., Zhu, Y., \& Li, B. (2017). Application of environmental performance analysis for urban design with Computational Fluid Dynamics (CFD) and EcoTect tools: the case of Cao Fei Dian eco-city, China. International Journal of Sustainable Built Environment, 6(1), 102-112. 
Choe, J. K., Mehnert, M. H., Guest, J. S., Strathmann, T. J., \& Werth, C. J. (2013). Comparative assessment of the environmental sustainability of existing and emerging perchlorate treatment technologies for drinking water. Environmental Science \& Technology, 47(9), 4644-4652.

Colazo, A. B., Sánchez, A., Font, X., \& Colón, J. (2015). Environmental impact of rejected materials generated in organic fraction of municipal solid waste anaerobic digestion plants: Comparison of wet and dry process layout. Waste Management, 43, 84-97.

Convertino, M., Baker, K. M., Vogel, J. T., Lu, C., Suedel, B., \& Linkov, I. (2013). Multi-criteria decision analysis to select metrics for design and monitoring of sustainable ecosystem restorations. Ecological Indicators, 26, 76-86.

De Groot, R. S., Blignaut, J., Van Der Ploeg, S., Aronson, J., Elmqvist, T., \& Farley, J. (2013). Benefits of investing in ecosystem restoration. Conservation Biology, 27(6), 1286-1293.

de Souza Junior, H. R. A., Dantas, T. E. T., Zanghelini, G. M., Cherubini, E., \& Soares, S. R. (2020). Measuring the environmental performance of a circular system: Emergy and LCA approach on a recycle polystyrene system. Science of the Total Environment, 726, 138111.

Den Hollander, M. C., Bakker, C. A., \& Hultink, E. J. (2017). Product design in a circular economy: Development of a typology of key concepts and terms. Journal of Industrial Ecology, 21(3), 517-525.

Dias, A. S., Kim, H., Sivakumar, P. K., Liu, Z. C., \& Zhang, H. C. (2013). Life cycle assessment: a comparison of manufacturing and remanufacturing processes of a diesel engine. In Re-engineering Manufacturing for Sustainability (pp. 675-678). Springer, Singapore.

Dong, Y., Miraglia, S., Manzo, S., Georgiadis, S., Sørup, H. J. D., Boriani, E., \& Hauschild, M. Z. (2018). Environmental sustainable decision making-the need and obstacles for integration of LCA into decision analysis. Environmental Science \& Policy, 87, 33-44.

dos Santos Pegoretti, T., Mathieux, F., Evrard, D., Brissaud, D., \& de França Arruda, J. R. (2014). Use of recycled natural fibres in industrial products: a comparative LCA case study on acoustic components in the Brazilian automotive sector. Resources, Conservation and Recycling, $84,1-14$.

Elia, V., Gnoni, M. G., \& Tornese, F. (2017). Measuring circular economy strategies through index methods: a critical analysis. Journal of Cleaner Production, 142, 2741-2751.

Eranki, P. L., El-Shikha, D., Hunsaker, D. J., Bronson, K. F., \& Landis, A. E. (2017). A comparative life cycle assessment of flood and drip irrigation for guayule rubber production using experimental field data. Industrial Crops and Products, 99, 97-108.

Feng, C., Gao, X., Tang, Y., \& Zhang, Y. (2014). Comparative life cycle environmental assessment of flue gas desulphurization technologies in China. Journal of Cleaner Production, 68, 81-92.

Feniser, C., Burz, G., Mocan, M., Ivascu, L., Gherhes, V., \& Otel, C. C. (2017). The evaluation and application of the TRIZ method for increasing eco-innovative levels in SMEs. Sustainability, 9(7), 1125.
Forchino, A. A., Lourguioui, H., Brigolin, D., \& Pastres, R. (2017). Aquaponics and sustainability: the comparison of two different aquaponic techniques using the Life Cycle Assessment (LCA). Aquacultural Engineering, 77, 80-88.

Friedler, E. (2004). Quality of individual domestic greywater streams and its implication for on-site treatment and reuse possibilities. Environmental Technology, 25(9), 997-1008.

García-Alcaraz, J. L., Montalvo, F. J. F., Cámara, E. M., de la Parte, M. M. P., Jiménez-Macías, E., \& Blanco-Fernández, J. (2020). Economic-environmental impact analysis of alternative systems for red wine ageing in re-used barrels. Journal of Cleaner Production, 244, 118783.

Garcia-Muiña, F. E., González-Sánchez, R., Ferrari, A. M., Volpi, L., Pini, M., Siligardi, C., \& Settembre-Blundo, D. (2019). Identifying the equilibrium point between sustainability goals and circular economy practices in an Industry 4.0 manufacturing context using eco-design. Social Sciences, 8(8), 241.

Godavitarne, C., Robertson, A., Peters, J., \& Rogers, B. (2017). Biodegradable materials. Orthopaedics and Trauma, 31(5), 316-320.

Goulet, B., Olson, L., \& Mayer, B. K. (2017). A comparative life cycle assessment between a metered dose inhaler and electric nebulizer. Sustainability, 9(10), 1725.

Guerra, J. P. M., Coleta, J. R., Arruda, L. C. M., Silva, G. A., \& Kulay, L. (2014). Comparative analysis of electricity cogeneration scenarios in sugarcane production by LCA. The International Journal of Life Cycle Assessment, 19(4), 814-825.

Habagil, M., Keucken, A., \& Sárvári Horváth, I. (2020). Biogas production from food residues - the role of trace metals and co-digestion with primary sludge. Environments, 7(6), 42.

Hauschild, M. Z., Rosenbaum, R. K., \& Olsen, S. I. (2018). Life cycle assessment. Springer.

Haziri, L. L., \& Sundin, E. (2019). Supporting design for remanufacturing-a framework for implementing information feedback from remanufacturing to product design. Journal of Remanufacturing, 1-20.

Hengen, T. J., Squillace, M. K., O’Sullivan, A. D., \& Stone, J. J. (2014). Life cycle assessment analysis of active and passive acid mine drainage treatment technologies. Resources, Conservation and Recycling, 86, 160-167.

Hooton, R. D., \& Bickley, J. A. (2014). Design for durability: the key to improving concrete sustainability. Construction and Building Materials, 67, 422-430.

Horbach, J., Rennings, K., \& Sommerfeld, K. (2015). Circular economy and employment. In 3rd IZA Workshop: Labor Market Effects of Environmental Policies.

Hossain, M. U., \& Poon, C. S. (2018). Comparative LCA of wood waste management strategies generated from building construction activities. Journal of Cleaner Production, 177, 387-397.

Hottle, T. A., Bilec, M. M., \& Landis, A. E. (2013). Sustainability assessments of bio-based polymers. Polymer Degradation and Stability, 98(9), 1898-1907.

ISO (2006a). 14040:2006 Environmental Management - LCA Principles and Framework.

ISO (2006b). 14044:2006 -Environmental Management - LCA - Requirements and Guidelines. 
Jachimowski, A., \& Nitkiewicz, T. (2019). Comparative analysis of selected water disinfection technologies with the use of life cycle assessment. Archives of Environmental Protection, 45(3).

Jones, C. H., Shilling, E. G., Linden, K. G., \& Cook, S. M. (2018). Life cycle environmental impacts of disinfection technologies used in small drinking water systems. Environmental Science \& Technology, 52(5), 2998-3007.

Joseph, T., Baah, K., Jahanfar, A., \& Dubey, B. (2015). A comparative life cycle assessment of conventional hand dryer and roll paper towel as hand drying methods. Science of the Total Environment, 515, 109-117.

Kalbusch, A., \& Ghisi, E. (2016). Comparative life-cycle assessment of ordinary and water-saving taps. Journal of Cleaner Production, 112, 4585-4593.

Karami, P., Al-Ayish, N., \& Gudmundsson, K. (2015). A comparative study of the environmental impact of Swedish residential buildings with vacuum insulation panels. Energy and Buildings, 109, 183-194.

Katsiropoulos, C. V., Loukopoulos, A., \& Pantelakis, S. G. (2019). Comparative environmental and cost analysis of alternative production scenarios associated with a helicopter's canopy. Aerospace, 6(1), 3.

Kemp, R. (2010). Eco-Innovation: Definition, measurement and open research issues. Economia Politica, 27(3), 397-420.

Keys, A., Baldwin, A., \& Austin, S. (2000). Designing to encourage waste minimisation in the construction industry. In CIBSE National Conference Dublin, Republic of Ireland.

Khalil, Y. F. (2018). Comparative environmental and human health evaluations of thermolysis and solvolysis recycling technologies of carbon fiber reinforced polymer waste. Waste Management, 76, 767-778.

Klemeš, J. J. (2012). Industrial water recycle/reuse. Current Opinion in Chemical Engineering, 1(3), 238-245.

Kriwet, A., Zussman, E., \& Seliger, G. (1995). Systematic integration of design-for-recycling into product design. International Journal of Production Economics, 38(1), 15-22.

Krystofik, M., Babbitt, C. W., \& Gaustad, G. (2014). When consumer behavior dictates life cycle performance beyond the use phase: Case study of inkjet cartridge endof-life management. The International Journal of Life Cycle Assessment, 19(5), 1129-1145.

Kwofie, E. M., \& Ngadi, M. (2017). A comparative lifecycle assessment of rural parboiling system and an integrated steaming and drying system fired with rice husk. Journal of Cleaner Production, 140, 622-630.

Lajunen, A., \& Lipman, T. (2016). Lifecycle cost assessment and carbon dioxide emissions of diesel, natural gas, hybrid electric, fuel cell hybrid and electric transit buses. Energy, 106, 329-342.

Landi, D., Marconi, M., Bocci, E., \& Germani, M. (2020). Comparative life cycle assessment of standard, cellulosereinforced and end of life tires fiber-reinforced hot mix asphalt mixtures. Journal of Cleaner Production, 248, 119295.

Leal, D., Winter, M. G., Seddon, R., \& Nettleton, I. M. (2020). A comparative life cycle assessment of innovative highway slope repair techniques. Transportation Geotechnics, $22,100322$.
Leino, M., Pekkarinen, J., \& Soukka, R. (2016). The role of laser additive manufacturing methods of metals in repair, refurbishment and remanufacturing-enabling circular economy. Physics Procedia, 83, 752-760.

Li, P., Froese, T. M., \& Cavka, B. T. (2018). Life cycle assessment of magnesium oxide structural insulated panels for a smart home in Vancouver. Energy and Buildings, 175, 78-86.

Lieder, M., Asif, F. M., Rashid, A., Mihelič, A., \& Kotnik, S. (2017). Towards circular economy implementation in manufacturing systems using a multi-method simulation approach to link design and business strategy. The International Journal of Advanced Manufacturing Technology, 93(5), 1953-1970.

Ling-Chin, J., Heidrich, O., \& Roskilly, A. P. (2016). Life cycle assessment (LCA)-from analysing methodology development to introducing an LCA framework for marine photovoltaic (PV) systems. Renewable and Sustainable Energy Reviews, 59, 352-378.

Liu, X., Guo, P., \& Guo, S. (2019). Assessing the eco-efficiency of a circular economy system in China's coal mining areas: Emergy and data envelopment analysis. Journal of Cleaner Production, 206, 1101-1109.

Liu, S., Schulz, U. W., Sapar, M. H., \& Qian, S. (2016). Evaluation of the environmental performance of the chilled ceiling system using life cycle assessment (LCA): a case study in Singapore. Building and Environment, 102, 207-216.

Liu, Z., Qiu, T., \& Chen, B. (2014). A study of the LCA based biofuel supply chain multi-objective optimization model with multi-conversion paths in China. Applied Energy, 126, 221-234.

Liu, C., Ahn, C. R., An, X., \& Lee, S. (2013). Life-cycle assessment of concrete dam construction: Comparison of environmental impact of rock-filled and conventional concrete. Journal of Construction Engineering and Management, 139(12), A4013009.

Lombardi, L., Tribioli, L., Cozzolino, R., \& Bella, G. (2017). Comparative environmental assessment of conventional, electric, hybrid, and fuel cell powertrains based on LCA. The International Journal of Life Cycle Assessment, 22(12), 1989-2006.

Lu, B., Du, X., \& Huang, S. (2017). The economic and environmental implications of wastewater management policy in China: From the LCA perspective. Journal of Cleaner Production, 142, 3544-3557.

Marino, F. P. R., \& Marrone, P. (2020). From lifespan to useful life, towards a new paradigm of durability for sustainable construction. TECHNE-Journal of Technology for Architecture and Environment, 148-156.

Mestre, A., \& Cooper, T. (2017). Circular product design. A multiple loops life cycle design approach for the circular economy. The Design Journal, 20(sup1), S1620-S1635.

Mohammed, F., Biswas, W. K., Yao, H., \& Tadé, M. (2016). Identification of an environmentally friendly symbiotic process for the reuse of industrial byproduct-An LCA perspective. Journal of Cleaner Production, 112, 3376-3387.

Mondello, G., Salomone, R., Ioppolo, G., Saija, G., Sparacia, S., \& Lucchetti, M. C. (2017). Comparative LCA of alternative scenarios for waste treatment: the case of food waste 
production by the mass-retail sector. Sustainability, 9(5), 827.

Montazeri, M., \& Eckelman, M. J. (2018). Life cycle assessment of UV-Curable bio-based wood flooring coatings. Journal of Cleaner Production, 192, 932-939.

Morris, J. (2017). Recycle, bury, or burn wood waste biomass?: LCA answer depends on carbon accounting, emissions controls, displaced fuels, and impact costs. Journal of Industrial Ecology, 21(4), 844-856.

Moussa, F. Z. B., Essaber, F. E., Benmoussa, R., \& Dubois, S. (2019). Enhancing eco-design methods using TRIZ tools: the case of ECOFAIRE. In International TRIZ Future Conference (pp. 350-367). Springer, Cham.

Mu, D., Seager, T., Rao, P. S., \& Zhao, F. (2010). Comparative life cycle assessment of lignocellulosic ethanol production: Biochemical versus thermochemical conversion. Environmental Management, 46(4), 565-578.

Nabavi-Pelesaraei, A., Bayat, R., Hosseinzadeh-Bandbafha, H., Afrasyabi, H., \& Berrada, A. (2017). Prognostication of energy use and environmental impacts for recycle system of municipal solid waste management. Journal of Cleaner Production, 154, 602-613.

Nakata, T., Kubo, K., \& Lamont, A. (2005). Design for renewable energy systems with application to rural areas in Japan. Energy Policy, 33(2), 209-219.

Nasr, N., \& Thurston, M. (2006). Remanufacturing: a key enabler to sustainable product systems. Rochester Institute of Technology, 15-18.

Ni, Z., Wang, Y., Wang, Y., Chen, S., Xie, M., Grotenhuis, T., \& Qiu, R. (2020). Comparative life-cycle assessment of aquifer thermal energy storage integrated with in situ bioremediation of chlorinated volatile organic compounds. Environmental Science \& Technology, 54(5), 3039-3049.

Oh, D., Lee, D., \& Jeong, S. (2019). Environmental impact evaluation on lightweight structure design of a composite ship by LCA (life cycle assessment). Journal of the Korean Society for Precision Engineering, 36(9), 875-881.

Opher, T., \& Friedler, E. (2016). Comparative LCA of decentralized wastewater treatment alternatives for non-potable urban reuse. Journal of Environmental Management, $182,464-476$.

Oró, E., Gil, A., De Gracia, A., Boer, D., \& Cabeza, L. F. (2012). Comparative life cycle assessment of thermal energy storage systems for solar power plants. Renewable Energy, 44, 166-173.

Ozkeser, B. (2018). An approach for sustainable innovation: TRIZ. New Trends and Issues Proceedings on Humanities and Social Sciences, 5(2), 67-73.

Ozbilen, A., Dincer, I., \& Rosen, M. A. (2013). Comparative environmental impact and efficiency assessment of selected hydrogen production methods. Environmental Impact Assessment Review, 42, 1-9.

Ozoemena, M., Cheung, W. M., \& Hasan, R. (2018). Comparative LCA of technology improvement opportunities for a 1.5-MW wind turbine in the context of an onshore wind farm. Clean Technologies and Environmental Policy, 20(1), 173-190.

Paccanelli, N., Teli, A., Scaglione, D., Insabato, G., \& Casula, A. (2015). Comparison based on environmental effects of nitrogen management techniques in a manure digestate case study. Environmental Technology, 36(24), 3176-3185.

Pardo, G., \& Zufía, J. (2012). Life cycle assessment of foodpreservation technologies. Journal of Cleaner Production, 28, 198-207.

Pintilie, L., Torres, C. M., Teodosiu, C., \& Castells, F. (2016). Urban wastewater reclamation for industrial reuse: An LCA case study. Journal of Cleaner Production, 139, 1-14.

Peng, S., Li, T., Wang, X., Dong, M., Liu, Z., Shi, J., \& Zhang, H. (2017). Toward a sustainable impeller production: Environmental impact comparison of different impeller manufacturing methods. Journal of Industrial Ecology, 21(S1), S216-S229.

Peters, K. (2016). Methodological issues in life cycle assessment for remanufactured products: a critical review of existing studies and an illustrative case study. Journal of Cleaner Production, 126, 21-37.

Poinssot, C., Bourg, S., Ouvrier, N., Combernoux, N., Rostaing, C., Vargas-Gonzalez, M., \& Bruno, J. (2014). Assessment of the environmental footprint of nuclear energy systems. Comparison between closed and open fuel cycles. Energy, 69, 199-211.

Postacchini, L., Mazzuto, G., Paciarotti, C., \& Ciarapica, F. E. (2018). Reuse of honey jars for healthier bees: Developing a sustainable honey jars supply chain through the use of LCA. Journal of Cleaner Production, 177, 573-588.

Pourzahedi, L., \& Eckelman, M. J. (2015). Comparative life cycle assessment of silver nanoparticle synthesis routes. Environmental Science: Nano, 2(4), 361-369.

Pranjić, A. M., Oprčkal, P., Mladenovič, A., Zapušek, P., Urleb, M., \& Turk, J. (2018). Comparative life cycle assessment of possible methods for the treatment of contaminated soil at an environmentally degraded site. Journal of Environmental Management, 218, 497-508.

Razza, F., Degli Innocenti, F., Dobon, A., Aliaga, C., Sanchez, C., \& Hortal, M. (2015). Environmental profile of a biobased and biodegradable foamed packaging prototype in comparison with the current benchmark. Journal of Cleaner Production, 102, 493-500.

Rew, Y., Shi, X., Choi, K., \& Park, P. (2018). Structural design and lifecycle assessment of heated pavement using conductive asphalt. Journal of Infrastructure Systems, 24(3), 04018019.

Rios, F. C., Chong, W. K., \& Grau, D. (2015). Design for disassembly and deconstruction-challenges and opportunities. Procedia Engineering, 118, 1296-1304.

Russo, D., \& Rizzi, C. (2014). Structural optimization strategies to design green products. Computers in Industry, 65(3), 470-479.

Saidani, M., Kravchenko, M., Cluzel, F., Pigosso, D., Leroy, Y., \& Kim, H. (2021). Comparing life cycle impact assessment, circularity and sustainability indicators for sustainable design: Results from a hands-on project with 87 engineering students. Proceedings of the Design Society, 1, 681-690.

Santagata, R., Zucaro, A., Viglia, S., Ripa, M., Tian, X., \& Ulgiati, S. (2020). Assessing the sustainability of urban eco-systems through emergy-based circular economy indicators. Ecological Indicators, 109, 105859.

Scalbi, S., \& Masoni, P. (2015). Comparative environmental assessment of nanofluid application in refrigeration of power electronic traction systems. 
Schakel, W., Meerman, H., Talaei, A., Ramírez, A., \& Faaij, A. (2014). Comparative life cycle assessment of biomass co-firing plants with carbon capture and storage. Applied Energy, 131, 441-467.

Schau, E. M., Traverso, M., \& Finkbeiner, M. (2012). Life cycle approach to sustainability assessment: a case study of remanufactured alternators. Journal of Remanufacturing, 2(1), 1-14.

Schreiber, A., Marx, J., \& Zapp, P. (2019). Comparative life cycle assessment of electricity generation by different wind turbine types. Journal of Cleaner Production, 233, 561-572.

Schulte, A., Maga, D., \& Thonemann, N. (2021). Combining life cycle assessment and circularity assessment to analyze environmental impacts of the medical remanufacturing of electrophysiology catheters. Sustainability, 13(2), 898.

Shen, L., Worrell, E., \& Patel, M. K. (2010). Open-loop recycling: a LCA case study of PET bottle-to-fibre recycling. Resources, Conservation and Recycling, 55(1), 34-52.

Shi, R., Handler, R. M., \& Shonnard, D. R. (2019). Life cycle assessment of novel technologies for algae harvesting and oil extraction in the renewable diesel pathway. Algal Research, 37, 248-259.

Shi, J., Li, T., Peng, S., Liu, Z., Zhang, H., \& Jiang, Q. (2015). Comparative life cycle assessment of remanufactured liquefied natural gas and diesel engines in China. Journal of Cleaner Production, 101, 129-136.

Simion, I. M., Fortuna, M. E., Bonoli, A., \& Gavrilescu, M. (2013). Comparing environmental impacts of natural inert and recycled construction and demolition waste processing using LCA. Journal of Environmental Engineering and Landscape Management, 21(4), 273-287.

Singhal, D., Tripathy, S., \& Jena, S. K. (2020). Remanufacturing for the circular economy: Study and evaluation of critical factors. Resources, Conservation and Recycling, $156,104681$.

Smol, M., Kulczycka, J., \& Avdiushchenko, A. (2017). Circular economy indicators in relation to eco-innovation in European regions. Clean Technologies and Environmental Policy, 19(3), 669-678.

Spreafico, C. (2021). Quantifying the advantages of TRIZ in sustainability through life cycle assessment. Journal of Cleaner Production, 126955.

Spreafico, C., Russo, D., \& Spreafico, M. (2021). Investigating the evolution of pyrolysis technologies through bibliometric analysis of patents and papers. Journal of Analytical and Applied Pyrolysis, 105021.

Spreafico, C., \& Russo, D. (2020). Assessing domestic environmental impacts through LCA using data from the scientific literature. Journal of Cleaner Production, 266, 121883.

Spreafico, C., \& Russo, D. (2021). A sustainable cheese packaging survey involving scientific papers and patents. Journal of Cleaner Production, 126196.

Sproesser, G., Chang, Y. J., Pittner, A., Finkbeiner, M., \& Rethmeier, M. (2015). Life cycle assessment of welding technologies for thick metal plate welds. Journal of Cleaner Production, 108, 46-53.

Stasiulaitiene, I., Martuzevicius, D., Abromaitis, V., Tichonovas, M., Baltrusaitis, J., Brandenburg, R., \& Schwock, A. (2016). Comparative life cycle assessment of plasma-based and traditional exhaust gas treatment technologies. Journal of Cleaner Production, 112, 1804-1812.

Sun, X., Meng, F., Liu, J., McKechnie, J., \& Yang, J. (2019). Life cycle energy use and greenhouse gas emission of lightweight vehicle-a body-in-white design. Journal of Cleaner Production, 220, 1-8.

Tagliaferri, V., Trovalusci, F., Guarino, S., \& Venettacci, S. (2019). Environmental and economic analysis of FDM, SLS and MJF additive manufacturing technologies. Materials, 12(24), 4161.

Tannous, S., Manneh, R., Harajli, H., \& El Zakhem, H. (2018). Comparative cradle-to-grave life cycle assessment of traditional grid-connected and solar stand-alone street light systems: a case study for rural areas in Lebanon. Journal of Cleaner Production, 186, 963-977.

Torres-Carrillo, S., Siller, H. R., Vila, C., López, C., \& Rodríguez, C. A. (2020). Environmental analysis of selective laser melting in the manufacturing of aeronautical turbine blades. Journal of Cleaner Production, 246, 119068.

Torroja, Y., Riesgo, T., de la Torre, E., \& Uceda, J. (1997). Design for reusability: Generic and configurable designs. Proceedings of System Modeling and Code Reusability, 11-21.

Van den Berg, M. R., \& Bakker, C. A. (2015). A product design framework for a circular economy. Product Lifetimes and the Environment, 365-379.

Vignali, G. (2017). Environmental assessment of domestic boilers: a comparison of condensing and traditional technology using life cycle assessment methodology. Journal of Cleaner Production, 142, 2493-2508.

Villanueva-Rey, P., Quinteiro, P., Vázquez-Rowe, I., Rafael, S., Arroja, L., Moreira, M. T., \& Dias, A. C. (2018). Assessing water footprint in a wine appellation: a case study for Ribeiro in Galicia, Spain. Journal of Cleaner Production, 172, 2097-2107.

Vinodh, S., Kamala, V., \& Jayakrishna, K. (2014). Integration of ECQFD, TRIZ, and AHP for innovative and sustainable product development. Applied Mathematical Modelling, 38(11-12), 2758-2770.

Vocciante, M., Caretta, A., Bua, L., Bagatin, R., Franchi, E., Petruzzelli, G., \& Ferro, S. (2019). Enhancements in phytoremediation technology: Environmental assessment including different options of biomass disposal and comparison with a consolidated approach. Journal of Environmental Management, 237, 560-568.

Voulvoulis, N. (2018). Water reuse from a circular economy perspective and potential risks from an unregulated approach. Current Opinion in Environmental Science \& Health, 2, 32-45.

Walker, S. B., Fowler, M., \& Ahmadi, L. (2015). Comparative life cycle assessment of power-to-gas generation of hydrogen with a dynamic emissions factor for fuel cell vehicles. Journal of Energy Storage, 4, 62-73.

Wang, C., Jin, H., Peng, P., \& Chen, J. (2019). Thermodynamics and LCA analysis of biomass supercritical water gasification system using external recycle of liquid residual. Renewable Energy, 141, 1117-1126.

Warsen, J., Laumer, M., \& Momberg, W. (2011). Comparative life cycle assessment of remanufacturing and new manufacturing of a manual transmission. In Glocalized 
Solutions for Sustainability in Manufacturing (pp. 67-72). Springer, Berlin, Heidelberg.

Wilson, J. M., Piya, C., Shin, Y. C., Zhao, F., \& Ramani, K. (2014). Remanufacturing of turbine blades by laser direct deposition with its energy and environmental impact analysis. Journal of Cleaner Production, 80, 170-178.

Wilson, J. M., Piya, C., Murray, V., Shin, Y., Zhao, F., \& Ramani, K. (2011). Laser-based remanufacturing of engineering components and its environmental impact analysis. In International Congress on Applications of Lasers \& Electro-Optics (Vol. 2011, No. 1, pp. 577-586). Laser Institute of America.

Wu, W., Cheng, L. C., \& Chang, J. S. (2020). Environmental life cycle comparisons of pig farming integrated with anaerobic digestion and algae-based wastewater treatment. Journal of Environmental Management, 264, 110512.

Xia, M., Shao, J., Qiao, M., Luo, Z., Deng, X., Ke, Q., \& Shen, L. (2020). Identification of LCA-binding glycans as a novel biomarker for esophageal cancer metastasis using a lectin array-based strategy. Journal of Cancer, 11(16), 4736.

Xiao, J., Wang, C., Ding, T., \& Akbarnezhad, A. (2018). A recycled aggregate concrete high-rise building: Structural performance and embodied carbon footprint. Journal of Cleaner Production, 199, 868-881.

Yan, X., Ward, S., Butler, D., \& Daly, B. (2018). Performance assessment and life cycle analysis of potable water production from harvested rainwater by a decentralized system. Journal of Cleaner Production, 172, 2167-2173.

Young, B., Krynock, M., Carlson, D., Hawkins, T. R., Marriott, J., Morelli, B., \& Skone, T. J. (2019). Comparative environmental life cycle assessment of carbon capture for petroleum refining, ammonia production, and thermoelectric power generation in the United States. International Journal of Greenhouse Gas Control, 91, 102821.

Yuan, P. S., Du, M. A., Huang, I. T., Liu, I. H., \& Chang, E. E. Chiang, P. C. (2014). Strategies on implementation of waste-to-energy (WTE) supply chain for circular economy system: a review. Journal of Cleaner Production, 108, 409-421.

Zakuciová, K., Štefanica, J., Carvalho, A., \& Kočí, V. (2020). Environmental assessment of a coal power plant with carbon dioxide capture system based on the activated carbon adsorption process: a case study of the Czech Republic. Energies, 13(9), 2251.
Zanchi, L., Delogu, M., Ierides, M., \& Vasiliadis, H. (2016). Life cycle assessment and life cycle costing as supporting tools for EVs lightweight design. In International Conference on Sustainable Design and Manufacturing (pp. 335-348). Springer, Cham.

Zea Escamilla, E., Habert, G., Correal Daza, J. F., Archilla, H. F., Echeverry Fernández, J. S., \& Trujillo, D. (2018). Industrial or traditional bamboo construction? Comparative life cycle assessment (LCA) of bamboo-based buildings. Sustainability, 10(9), 3096.

Zhang, J. H., \& Chen, M. (2015). Assessing the impact of China's vehicle emission standards on diesel engine remanufacturing. Journal of Cleaner Production, 107, 177-184.

Zhang, Q. H., Wang, X. C., Xiong, J. Q., Chen, R., \& Cao, B. (2010). Application of life cycle assessment for an evaluation of wastewater treatment and reuse project-case study of Xi'an, China. Bioresource Technology, 101(5), 1421-1425.

Zhang, C., \& Xu, Y. (2020). Economic analysis of large-scale farm biogas power generation system considering environmental benefits based on LCA: a case study in China. Journal of Cleaner Production, 258, 120985.

Zhang, X., Zhang, M., Zhang, H., Jiang, Z., Liu, C., \& Cai, W. (2020). A review on energy, environment and economic assessment in remanufacturing based on life cycle assessment method. Journal of Cleaner Production, 255, 120160.

Zheng, H., Li, E., Wang, Y., Shi, P., Xu, B., \& Yang, S. (2019). Environmental life cycle assessment of remanufactured engines with advanced restoring technologies. Robotics and Computer-Integrated Manufacturing, 59, 213-221.

Zhu, L., Guo, W., Yin, S., \& Wang, S. (2015). Comparative life cycle assessment of ethanol synthesis from corn stover by direct and indirect thermochemical conversion processes. Energy \& Fuels, 29(12), 7998-8005.

Zunft, J., \& Fröhlig, B. (2009). Energy from waste-Zukunftsmärkte Europa. Fachtag. Therm. Abfallbehandl, 14, 17.

Publisher's Note Springer Nature remains neutral with regard to jurisdictional claims in published maps and institutional affiliations. 